\title{
Temporal changes in the causes of the observed oxygen decline in the St. Lawrence Estuary
}

\author{
M. Jutras ${ }^{1}$, C. O. Dufour ${ }^{2}$, A. Mucci ${ }^{1,3}$, F. Cyr ${ }^{4,5}$, and D. Gilbert ${ }^{6}$ \\ ${ }^{1}$ Department of Earth and Planetary Sciences, McGill University, Montreal, QC, Canada \\ ${ }^{2}$ Department of Atmospheric and Oceanic Sciences, McGill University, Montreal, QC, Canada \\ ${ }^{3}$ Geotop, Universit du Qubec Montral, Montreal, QC, Canada \\ ${ }^{4}$ Northwest Atlantic Fisheries Centre, Fisheries and Oceans Canada, St. John's, NL, Canada \\ ${ }^{5}$ Department of Physics and Physical Oceanography, Memorial University of Newfoundland, St. \\ John's, NL, Canada \\ ${ }^{6}$ Maurice-Lamontagne Institute, Fisheries and Oceans Canada, Mont-Joli, QC, Canada
}

\begin{abstract}
Oxygen concentrations in the deep waters of the Lower St. Lawrence Estuary have decreased by 50\% over the past century. The drivers of this decrease are investigated by applying an extended Optimum Multiparameter (eOMP) analysis to a time series of physical and biogeochemical observations of the St. Lawrence Estuarine System in the 1970s and from late 1990s to 2018. This method reconstructs the relative contributions of the two major water masses feeding the system, the Labrador Current Waters (LCW) and the North Atlantic Central Waters (NACW), as well as oxygen utilization, and accounts for diapycnal mixing. The causes of the oxygen decline varied over the last five decades. Between the 1970s and late 1990s, the decrease was mainly driven by biogeochemical changes through an increase in microbial oxygen utilization in the St. Lawrence Estuary in response to warmer temperatures and eutrophication and lower oxygen concentrations in LCW and NACW. Between 2008 and 2018, the decrease was mainly driven by circulation changes in the western North Atlantic associated with a reduced inflow of high-oxygenated LCW to the deep waters of the system in favour of low-oxygenated NACW, reaching a historical minimum in 2016. The LCW:NACW ratio is strongly correlated with the volume transport of the Scotian shelf-break current, an extension of the Labrador Current. These results highlight the primary role of the Labrador Current in determining the oxygen concentration and other water properties of the St. Lawrence Estuarine System and on the western North Atlantic continental shelf and slope.
\end{abstract}

Mathilde Jutrasmathilde.jutras@mail.mcgill.ca

\section{Keypoints}

- The causes of the observed decrease in oxygen concentrations at the head of the Lower St.

Lawrence Estuary varied over the last 50 years.

- The oxygen decline is driven by biogeochemical changes over 1970-1995, and by circulation changes in the North Atlantic over 2008-2018.

- Inflow of oxygen-rich Labrador Current waters to the Estuary correlates with the strength (or transport) of the Scotian Shelf break current.

\section{Plain Language Summary}

Over the past century, the oxygen concentrations of the deep waters of the Lower St. Lawrence Estuary have declined dramatically, with dire consequences to marine life and the fishing industry. Two processes are thought to be responsible for this decline. First, nutrient and organic matter discharge from urban and agricultural activities in its drainage basin promote algae blooms, which are decomposed by bacteria that consume oxygen in the deep waters, a mechanism called eutrophication. Second, the oxygen-rich Labrador waters feeding the deep waters of the estuary have been progressively replaced by oxygen-poor Gulf Stream waters. Using observations and a water mass reconstruction method, we determined to what extent each of the above processes contributed to the oxygen decline over the last five decades. Between the 1970s and early 1990s, the oxygen decline was mostly due to biogeochemical changes (including eutrophication). From 2008 to 2018, the decline

This article has been accepted for publication and undergone full peer review but has not been through the copyediting, typesetting, pagination and proofreading process, which may lead to differences between this version and the Version of Record. Please cite this article as doi: 10.1029/2020JC016577. 
was mostly due to a reduction in the amount of Labrador waters feeding the system. Understanding how circulation in the Northwest Atlantic ocean influences oxygen concentrations along the coast is crucial, given that circulation patterns vary naturally with time and could be affected by climate change.

\section{Introduction}

Over the last decades, many coastal and estuarine environments have experienced a dramatic decline in dissolved oxygen concentrations (Bindoff et al., 2019; Breitburg 57 et al., 2018; Rabalais et al., 2010; Gilbert et al., 2010), with dire consequences on marine ecosystems and biogeochemical cycles (Breitburg et al., 2018; Rabalais et al., 2014). One such environment is the St. Lawrence Estuarine System in eastern Canada, the largest semi-enclosed estuary in the world (Fig.1). Over the past century, the Lower St. Lawrence Estuary has seen its deep-water oxygen concentrations decrease by more than $50 \%$, going from $\sim 125 \mu \mathrm{mol} \mathrm{kg}^{-1}$ in the 1930 s to less than $60 \mu \mathrm{mol} \mathrm{kg}^{-1}$ in recent years (Gilbert et al., 2005, see Fig. 2b). This decrease has a direct impact on marine fauna and fisheries, including cod growth and distribution (Chabot \& Dutil, 1999; D'Amours, 1993) and northern shrimp viability (Dupont-Prinet et al., 2013).

The St. Lawrence Estuarine System extends from Quebec City to the Atlantic Ocean and is traditionally divided into the Upper Estuary, the Lower Estuary and the Gulf of St. Lawrence. Its most prominent bathymetric feature is the Laurentian Channel (LC), a 300-500 m deep channel that stretches $1240 \mathrm{~km}$ landward from the continental shelf break to the head of the Lower Estuary (Fig.1). The circulation of the system is estuarine, with surface water flowing seaward and the Cold Intermediate Layer, formed in the winter in the Gulf (Galbraith, 2006; Gilbert \& Pettigrew, 1997), and deep waters, of North Atlantic origin, flowing landward (Dickie \& Trites, 1983). As deep waters flow along the Laurentian Channel into the St. Lawrence Estuary, a journey that takes four to seven years from the continental shelf break to the head of the channel, they progressively lose oxygen through microbial respiration of settling particulate matter (Gilbert, 2004; Bugden, 1991). As a result, waters at the head of the Laurentian Channel are depleted in oxygen compared to the North Atlantic waters (Fig.2a). In recent decades, observations have revealed increased respiration rates Genovesi et al., 2011) under higher deep-water temperatures (Gilbert et al., 2005) and eutrophication (Jutras et al., 2020; Thibodeau et al., 2018). The latter is fostered by an increase in organic matter and nutrient exports to the estuary's main tributary, the St. Lawrence River (Environment and Climate Change Canada, 2018; Goyette et al., 2016), that drains highly populated and industrialized areas as well as intensively farmed lands (Hudon et al., 2017). The deep waters entering the Laurentian Channel from the North Atlantic are a combination of cold, oxygen-rich shelf and offshore Labrador Current waters (hereafter called LCW, see section 2 for definition), and warm, oxygen-poor North Atlantic Central Waters (NACW) that mix on the continental slope to form Cold Slope waters (Fig. 1, Gilbert et al., 2005; Bugden, 1991; Gatien, 1976). Circulation patterns and water properties of the western North Atlantic Ocean therefore impact water properties in the estuary, including oxygen concentrations (Thibodeau et al., 2018; Claret et al., 2018).

An analysis of the average of physical properties of the deep waters of the Lower St. Lawrence Estuary between the early 1930s and 2003 showed that one-half to two-thirds of the observed oxygen decline at the head of the Laurentian Channel was caused by an increase in the relative contribution of NACW to the deep waters (Gilbert et al., 2005), while the remainder was attributed to eutrophication. These results can now be revisited with an additional 15 years of observations collected at higher frequency in the St. Lawrence Estuary and Gulf, allowing for an assessment of the interannual variability of the contributions of LCW and NACW to the St. Lawrence Estuarine System and a quantification of the different causes of the oxygen decline. Furthermore, previous estimates of the LCW:NACW mixing ratio in Laurentian Channel waters were derived from temperature-salinity (TS) diagrams (Gilbert et al., 2005; Bugden, 1991), a method that assumes that mixing only takes place along isopycnals. Diapycnal mixing is known to be important along continental shelves (Gregg et al., 1999) and on the fringe of the Gulf Stream (Rodríguez-Santana et al., 1999; Pelegri \& Csanady, 1994; Churchill et al., 1993), and the North Atlantic waters reach the eastern American continental shelf through turbulent (diapycnal) mixing and double-diffusion of thin water intrusions, forced by tides

This article is protected by copyright. All rights reserved. 
and shear (Nash et al., 2004; Herman \& Denman, 1979; Voorhis et al., 1976). Hence, diapycnal mixing should be considered when investigating changes in the LCW:NACW ratio entering the St. Lawrence Estuarine System.

The eastern American shelf and Slope waters are influenced by oceanic circulation in the North Atlantic. In particular, the properties of these waters are strongly affected by the extent of westward intrusions of Labrador waters along the continental slope (Pershing et al., 2001), which are formed as the main branch of the Labrador Current hugs the Grand Banks and makes its way southwest between the Gulf Stream and the shelf (Fig. 1, Townsend et al., 2006; Schollaert et al., 2004; Gatien, 1976). The factors that control the extent of these intrusions remain unclear. A first possibility is that the intrusions are controlled by the North Atlantic Oscillation (NAO, Pershing et al., 2001; Loder et al., 2001) or the Atlantic Meridional Overturning Circulation (AMOC, Claret et al., 2018; Thibodeau et al., 2018). A slower AMOC is expected under climate change (Stouffer et al., 2006) and was recently found in some observational studies (Caesar et al., 2018; Thornalley et al., 2018). A positive phase of the NAO or a slowdown of the AMOC would lead to a contraction of the subpolar gyre (e.g., Lohmann et al., 2009; Taylor \& Stephens, 1998), a northern shift of the Gulf Stream (Joyce \& Zhang, 2010) and a reduction of the transport of LCW southwest of the Grand Banks, leading to an increased contribution of NACW over LCW to the Cold Slope waters (Townsend et al., 2015). Until the 1990s, the NAO co-varied with Slope waters properties and with the number of warm Gulf Stream eddies reaching the shelf (Mountain, 2012; Petrie, 2007; Luo et al., 2006; Greene \& Pershing, 2003; Pershing et al., 2001; Drinkwater et al., 1998). However, these relationships have weakened since the 1990s (Peterson et al., 2017; Townsend et al., 2015; Gangopadhyay et al., 2019; Gawarkiewicz et al., 2018). These conflicting results suggest that the forcing scenario and resultant change in the circulation pattern described above are incomplete and cannot fully predict oxygen concentrations on the shelf. A second possibility, which is supported by our results, is that the reach of the Labrador water intrusions and, hence, water properties on the slope, are controlled by the volume transport of the Labrador Current (Holliday et al., 2020; Grodsky et al., 2017; Urrego-Blanco \& Sheng, 2012; Pickart et al., 1999; Rossby, 1999; Petrie \& Drinkwater, 1993). The Labrador Current properties are partly controlled by the strength of the subpolar gyre and the Arctic exports through Davis and Hudson straits (Loder et al., 1998), but the processes driving its variability are poorly known (Holliday et al., 2020).

In this study, we investigate the causes of the observed oxygen decline in the Lower St. Lawrence Estuary since the 1970s. To do so, we revisit the conclusions of previous observation-based studies on the changes in the LCW:NACW ratio of the deep waters entering the Gulf and St. Lawrence Estuary through Cabot Strait. We use a set of new, higher frequency observations of the physical and biochemical properties of waters in the St. Lawrence Estuary and Gulf and an extended Optimum Multiparameter (eOMP) analysis. This method provides the LCW:NACW proportions and a quantification of oxygen consumption, and accounts for both isopycnal and diapycnal mixing (Tomczak et al., 1994). We first document the interannual variability in the LCW:NACW ratio and in oxygen utilization since the late 1990s, with some additional data from the 1970s (section 3.1 and 3.2). We then partition the oxygen decline at the head of the Laurentian Channel into its physical and biogeochemical drivers for different periods of time (section 3.3), and link the circulation changes in the western North Atlantic to the variability of oxygen concentrations at the entrance to the Gulf (section 3.4).

Figure 1: Map of the St. Lawrence Estuary and Gulf. The insert on the left shows the St. Lawrence Estuary drainage basin in light red. Arrows give the approximate positions of the Labrador Current, the Gulf Stream and the Scotian shelf-break Current. The grey dotted line corresponds to the transect along the Laurentian Channel investigated in this study. The red star designates the head of the Laurentian Channel, where the oxygen decline is maximal and hypoxic waters are found. The red box represents the section near Cabot Strait over which the results are averaged (see Section 3.1). The yellow-grey dashed line shows the Seal Island hydrographic section.

Figure 2: Dissolved oxygen concentrations in the Laurentian Channel. (a) Annual climatology (1980-2018) along the Laurentian Channel. Distance are reported from Quebec City, with black triangles showing the position of important geographical features of the Laurentian Channel. QC:

This article is protected by copyright. All rights reserved. 
Quebec City; HLC: head of the Laurentian Channel; G: boundary between the Estuary and the Gulf; CS: Cabot Strait. (b) Time series of dissolved oxygen concentration at the oxygen minimum depth at the head of the Laurentian Channel. Data are from the BioChem and Coriolis datasets (see Section 2.1). The error bars represent the standard deviation. No estimate of the uncertainty is available for the 1970s data.

\section{Data and Methods}

\subsection{Data}

\subsection{Observations in the St. Lawrence Estuarine System}

We use in-situ observations sampled throughout the water column from two datasets. The first dataset is the Coriolis dataset (Mucci \& Jutras, 2020), a collection of physical (temperature, salinity) and biogeochemical (oxygen, nitrate, soluble reactive phosphate, silicate, total alkalinity, and water oxygen isotopic composition $\delta^{18} \mathrm{O}\left(\mathrm{H}_{2} \mathrm{O}\right)$ ) variables sampled between 2003 and 2018 in spring and summer at over 10 stations along the Laurentian Channel on board the R/V Coriolis II (460 data points; for a detailed description of data sampling techniques see Dinauer \& Mucci, 2017). The second dataset was extracted from the BioChem database compiled by the Department of Fisheries and Oceans Canada. This dataset provides quality-controlled data for the same variables as the Coriolis dataset except for $\delta^{18} \mathrm{O}\left(\mathrm{H}_{2} \mathrm{O}\right)$ and covers the Gulf and St. Lawrence Estuary from 1967 to 1972, and from 1991 to 2018 (8,915 data points, DFO, 2019; Devine et al., 2014). A detailed description of data sampling techniques and quality control can be found in Devine et al. (2014) and Mitchell et al. (2002). We applied an additional quality control to the two datasets, removing outliers based on T-S or property-S diagrams and correcting inconsistencies in units.

\subsection{Observations on the Labrador Shelf}

Data from the Seal Island (SI, Fig. 1) hydrographic section on the Labrador shelf were collected as part of the Atlantic Zone Monitoring Program (AZMP, Therriault et al., 1998). We use summer data corresponding to 1745 discrete water samples collected at standard depths along this section between 1999 and 2018. For each year, data were collected between July $15^{\text {th }}$ and August $10^{\text {th }}$. Physical (temperature and salinity) and biogeochemical (oxygen and nutrient concentrations) data were collected following the AZMP sampling protocol (Mitchell et al., 2002). From these data, we compute time series of water properties at each station by averaging the data below $50 \mathrm{~m}$ (Fig. 4). To remove vertical sampling biases, we bring each data point to a reference depth by applying a correction equal to the difference in the climatology between the reference depth and the sampled depth, following Stendardo and Gruber (2012).

\subsection{Climatologies of the North Atlantic}

The hydrographic properties of LCW and NACW are defined based on the World Ocean Circulation Experiment (WOCE; Gouretski, 2018) climatology of temperature, salinity, as well as oxygen and nutrient concentrations re-gridded to a $1^{\circ} \times 1^{\circ}$ grid. The World Ocean Database World Ocean Database (WOD, Boyer et al., 2013) $1^{\circ} \times 1^{\circ}$ climatology is used for total alkalinity and $\delta^{18} \mathrm{O}$.

\subsection{Atmospheric and oceanic products and indices}

To investigate the influence of the North Atlantic Ocean circulation on the origin of waters entering the St. Lawrence Estuarine System, we use the following atmospheric and oceanic products.

1 NCEP-NCAR wind reanalysis over the Gulf of St. Lawrence and western North Atlantic for the 1953-2018 period (Kalnay et al., 1996). Seasonal winds are averaged over the 1995-2016 period to obtain a wind climatology;

2 Position through time of the Gulf Stream North Wall and of the Shelf-Slope Front, computed from sea surface temperatures (SST) by the Bedford Institute of Oceanography using the methodology

This article is protected by copyright. All rights reserved. 
described in Drinkwater (1994), and available at http: / /www. meds-sdmm.dfompo.gc.ca/alphapro/zmp/climate/GulfSlope/odf_data_files/GSMNTHMN_Mon thly_Averages.odf and http://www.meds-sdmm.dfo-

mpo.gc.ca/alphapro/zmp/climate/GulfSlope/odf_data_files/SSMNTHMN_Mon thly_Averages.odf;

3 Time series of (a) the Gulf Stream delta index, a proxy for Gulf Stream intensity computed from SST differences across the Gulf Stream North Wall front (Watelet et al., 2017), (b) the Gulf Stream index, a proxy for the variability in the position (latitude) of the Gulf Stream based on sea surface height (SSH) anomalies obtained from satellite altimetry (Pérez-Hernández \& Joyce, 2014; Joyce \& Zhang, 2010), and (c) the Scotian shelf-break Current and Labrador Current transport indices, also derived from satellite altimetry and representative of the volume flux per unit of time of those currents (Cyr et al., 2020; Han et al., 2014);

4 Time series of the subpolar gyre index (SPGi), derived from the first principal component of SSH anomalies obtained from satellite altimetry (Hátún \& Chafik, 2018), available at https://bolin.su.se/data/chafik-2019-2;

5 An index of the North Atlantic Oscillation (NAO) published by the National Oceanic and Atmospheric Administration (NOAA) and available at https://www.cpc.ncep.noaa.gov/data/teledoc/nao.shtml.

\subsection{Method: Extended Optimum Multiparameter (eOMP) analysis}

Changes in the oxygen concentrations in the deep waters of the Gulf and St. Lawrence Estuary over the past 50 years result in part from changes in the relative contributions of two parent-water masses entering the St. Lawrence Estuarine System through Cabot Strait: LCW, NACW, and a third water mass partly formed in situ and partly advected through the Strait of Belle-Isle, the Cold Intermediate Layer (CIL). We investigate these changes and biogeochemical changes through an extended Optimum Multiparameter (eOMP) analysis method, introduced by Tomczak (1981) and extended by Karstensen and Tomczak (1998) and Tomczak and Large (1989),, that we applied to hydrographic data from the St. Lawrence Estuarine System. From the physico-chemical properties of parent-water masses, the eOMP method determines the relative contributions of each parent-water mass to the parcel of water whose properties are described by hydrographic data. To do so, the eOMP fits the best solution to an overdetermined linear mixing model. In its original configuration, the method used conservative properties upon mixing. In the extended version, "semi-conservative" properties affected solely by respiration and photosynthesis are also solved for, assuming they co-vary according to a set stoichiometry, providing an estimate of biogeochemical activity.

\section{7 the eOMP method}

The system of linear equations used in the eOMP analysis is:

$$
\begin{aligned}
& \mathrm{x}_{1} \mathrm{~A}_{1}+\ldots+\mathrm{x}_{\mathrm{n}} \mathrm{A}_{\mathrm{n}}+0=\mathrm{A}_{\mathrm{obs}}+\mathrm{R}_{\mathrm{A}} \\
& x_{1} B_{1}+\ldots+x_{n} B_{n}+0=B_{o b s}+R_{B} \\
& x_{1} K_{1}+\ldots+x_{n} K_{n}+\Delta K=K_{o b s}+R_{K} \\
& \mathrm{x}_{1} \mathrm{~L}_{1}+\ldots+\mathrm{x}_{\mathrm{n}} \mathrm{L}_{\mathrm{n}}+\mathrm{r}_{\mathrm{K}: \mathrm{L}} \Delta \mathrm{K}=\mathrm{L}_{\mathrm{obs}}+\mathrm{R}_{\mathrm{L}} \\
& x_{1}+\ldots+x_{n}+0=1+R_{V}
\end{aligned}
$$

Equations 1a-d describe the mixing of $N$ variables, or water properties, referred to with a capital letter. Eq. 1e accounts for volume conservation (the fractions of all water masses must add to 1). On the lefthand side of the equations, $x_{i}(\mathrm{i}=1, \ldots, \mathrm{n})$ are the mixing fractions of the $n$ parent-water masses. On the right-hand side of the equations, $X_{o b s}$ and $R_{X}$ are, respectively, the measurements in the child water mass and the residuals associated with each variable $X$ (or $V$ for volume; Eq. 1e). Equations for

This article is protected by copyright. All rights reserved. 
semi-conservative variables have an additional term (last term on the left-hand side of Eq. 1c-d) that corresponds to sources and sinks. $\Delta \mathrm{K}$ is the change in the semi-conservative biogeochemical variable $K$ that co-varies with other semi-conservative variables through the stoichiometric ratios $\mathrm{r}_{\mathrm{K}: \mathrm{X}}$. The standard stoichiometric ratios are used (Hedges et al., 2002), except for the $N: P$ ratio which is affected by strong denitrification in the Lower St. Lawrence Estuary (Thibodeau et al., 2010). That ratio is determined from the correlations of $N$ and $P$ measurements in the Laurentian Channel from the Biochem database. The ratios we use are as follows: $\mathrm{O}_{2}: \mathrm{PO}_{4}: \mathrm{NO}_{3}: \mathrm{Si}=-150: 1: 12: 40$.

We solved the linear set of equations described in Eq. 1 with an adaptation of the Geomar OMP Analysis Package for MATLAB (Karstensen \& Tomczak, 1999) available at omp.geomar. de/. The fractions $x_{i}$ are the main result of the eOMP, but two additional outputs are also provided: the residuals $R_{j}$ and the change in the biogeochemical variable $K, \Delta K$. The algorithm solves the system of equations by applying a least-square minimization on the sum of residuals, $\sum_{j=1}^{N} R_{j}+R_{V}$. To allow for this minimization, the system needs to be overdetermined (more equations than unknowns). In other words, we need at least one more variable than the number of parent-water masses. Water mass definitions are given as a range of values (e.g., for salinity, $34<S_{P}<35$; Table 1) and hence each water mass is described with two terms in Eq. 1. The number of variables have to be adjusted accordingly (Karstensen \& Tomczak, 1998). Alternatively, to reduce the number of required variables, the parent-water masses can be defined using a single water type (single-value definition; e.g. $S_{P}=34.5$ ).

Variables do not all have the same level of reliability, depending on measurement accuracy and variability in the region of water mass definition. Each equation is therefore assigned a weight (Tomczak \& Large, 1989). For a given variable $\mathrm{j}=\{1, \ldots, \mathrm{N}\}$, the weight $w_{j}$ is calculated from the inverse of the average variance of climatological data around the parent-water mass definitions (Karstensen \& Tomczak, 1999),

$$
w_{j}=\frac{1}{L} \sum_{l=1}^{L}\left(\frac{1}{\sqrt{\sigma_{l}^{2}}}\right)
$$

where we sum over the $L$ points participating to the water mass definition (see spread around black lines in Fig. 3b-c).

Whereas the eOMP has a number of advantages over the T-S diagram method, it still has some limitations. Three assumptions can cause systematic errors: identical mixing coefficients for all variables (Klein \& Tomczak, 1994), linearity of the equation of state, and straight line water-mass definitions (Tomczak, 1981). The first assumption could be problematic when double diffusion contributes to the mixing, but the induced error is insignificant most of the time (Klein \& Tomczak, 1994). The second assumption induces an error of $2-4 \%$, well within the uncertainty from other sources (see below). The impact of the third assumption can be minimized by constraining the analysis to a range of densities over which the definitions are close to a straight line, or by using more than two water types (see next section). Rather, the most significant sources of error of the eOMP method are uncertainties in water mass definitions and sensitivity to measurement errors (Tomczak, 1981). These errors can be minimized by running the analysis on multiple measurements close in location and time, as we do in this analysis. We quantify these errors with a sensitivity analysis by perturbing the parent-water mass definitions by one standard deviation. Fractions are robust, with deviations $<5 \%$ except near the sill at the head of the Laurentian Channel, where the imposed perturbations produce large variations of up to $40 \%$. Hence, results near the sill should be given lower confidence than those in other regions. The results are also robust to perturbations in the stoichiometric ratios ( $\sim 10 \%$ deviations for a $50 \%$ perturbation on the weights for half of the variables) and weights ( $\sim 3 \%$ deviations for a $10 \%$ perturbation on the ratios for half of the variables).

This article is protected by copyright. All rights reserved. 
The data points for which the eOMP yielded a total residual $\left(\sum R_{j}+R_{V}\right)$ larger than $5 \%$ were discarded.

\subsection{Parent-water mass definitions}

This section presents the rationale leading to the parent-water mass definitions provided in Table 1. At the surface, the physico-chemical properties of water can be altered by multiple processes in addition to mixing, including gas and heat exchange, atmospheric depositions, precipitation and evaporation, as well as river inputs. Waters with depths $<100 \mathrm{~m}$ are thus discarded from the eOMP analysis. Three parent-water masses compose the waters of the Gulf and Lower Estuary below $100 \mathrm{~m}$. The cold intermediate layer (CIL) is a remnant of the winter well-oxygenated mixed layer formed in the Gulf and of Labrador shelf waters advected via the Strait of Belle Isle (Galbraith, 2006; Gilbert \& Pettigrew, 1997). What we refer to as the Labrador Current Waters (LCW) are a combination of waters from the main branch of the Labrador Current, which flows along the Labrador slope and around the Grand Banks, and waters from the inner branch of the Labrador Current, which flows on the Labrador Shelf and through the Avalon Channel, both feeding a range of isopycnals in the Laurentian Channel (Brickman et al., 2016; Townsend et al., 2015; Wang et al., 2015; Fratantoni \& Pickart, 2007; Loder et al., 1998, and Fig. 1). The North Atlantic Central Waters (NACW) also originate from the North Atlantic where they are carried north by the Gulf Stream.

Prior to running the eOMP analysis, the three parent-water masses need to be defined in terms of their physico-chemical properties. The definitions are based on in-situ observations in the Gulf for the CIL, and on the WOCE and WOD climatologies for the LCW and NACW, by averaging the values within the regions and depths ranges where each water mass is located (Fig. 3a). The regions and depth ranges are identified based on the literature (Stendardo \& Gruber, 2012; Emery \& Meincke, 1986) and by choosing areas with relatively uniform properties through visual inspection. The definitions are then given as a range of values (described with two water types), except for the NACW. The latter is best described by three water types, given their v-shape in salinity-property space (Fig. 3b-c). Due to discontinuity in the data availability, the CIL uses a range or a single-value definition depending on the year (see section 2.9). The definitions are given for four conservative variables: temperature $(T)$, practical salinity $\left(S_{P}\right)$, the stable oxygen isotopic composition of water $\left(\delta^{18} \mathrm{O}\left(\mathrm{H}_{2} \mathrm{O}\right)\right.$ ) and total alkalinity ( TA), and for four semi-conservative variables: dissolved oxygen $\left(\mathrm{O}_{2}\right)$, nitrate $\left(\mathrm{NO}_{3}^{-}\right)$, soluble reactive phosphate ( $S R P)$ and dissolved silicate $(d S i)$ concentrations.

Figure 3: Definition of the parent-water masses used in the eOMP analysis. (a) Regions and depth ranges used for the definitions. Property-salinity diagrams of (b) $\mathrm{T}$ versus $\mathrm{S}_{P}$ and (c) $\mathrm{O}_{2}$ versus $\mathrm{S}_{P}$. In (b-c), colored dots show the values from WOD and WOCE gridded climatologies for LCW and NACW, and from BioChem data for the CIL, in the regions and over the depth ranges given in (a). Black segments show the range of values used for the water-mass definitions (Table 1). For the CIL, we also use a single value definition for some years (black circle in b and c) (see Section 2.7). In (b), grey lines show isopycnals, and black dots represent the hydrographic data within the Laurentian Channel. The zones delimited by the green and red dotted lines represent, respectively, the Cold (or Labrador) Slope Waters and the Warm Slope Waters, as identified in the Slope Sea by Gatien (1976).

Table 1: Parent-water mass definitions

\begin{tabular}{|l|l|l|l|l|}
\hline & & \multicolumn{3}{|c|}{ Water masses } \\
\hline & & CIL & NACW & LCW \\
\hline Variables & T & $-0.6-1.5(0)$ & $4.4-8.0-17.7$ & $-0.7-3.2$ \\
\hline & $\left({ }^{\circ} \mathrm{C}\right)$ & $( \pm 1.1)$ & $( \pm 0.2)$ & $( \pm 0.2)$ \\
\hline & $\mathbf{S}_{P}$ & $31.8-33(32.2)$ & $35.0-35.2-36.5$ & $33.4-35.0$ \\
\hline & $(\mathrm{psu})$ & $( \pm 0.5)$ & $( \pm 1.2)$ & $( \pm 0.5)$ \\
\hline
\end{tabular}

This article is protected by copyright. All rights reserved. 


\begin{tabular}{|l|l|l|l|l|}
\hline & $\mathbf{N O}_{3}{ }^{-}$ & $1.7-12.0(5.8)$ & $17.5-22-4.8$ & $10-17$ \\
\hline & $(\mu \mathrm{mol} / \mathrm{kg})$ & $( \pm 3.8)$ & $( \pm 4)$ & $( \pm 1.4)$ \\
\hline & $\mathbf{S R P}$ & $0.6-1.2(0.8)$ & $1.15-1.38-0.24$ & $0.4-1.1$ \\
\hline & $(\mu \mathrm{mol} / \mathrm{kg})$ & $( \pm 0.2)$ & $( \pm 0.2)$ & $( \pm 0.2)$ \\
\hline & $\mathbf{d S i}$ & $1.0-13.0(4.8)$ & $12.5-14.8-1.9$ & $1.6-11.0$ \\
\hline & $(\mu \mathrm{mol} / \mathrm{kg})$ & $( \pm 5)$ & $( \pm 3)$ & $( \pm 4)$ \\
\hline & $\mathbf{O}_{2}$ & $366-266(348)$ & $250-155-195$ & $310-280$ \\
\hline & $(\mu \mathrm{mol} / \mathrm{kg})$ & $( \pm 38)$ & $( \pm 47)$ & $( \pm 7)$ \\
\hline & $\delta^{18} \mathbf{O}$ & $-1.5--1.5(-1.5)$ & $0.29-0.35-1.00$ & $-0.55-0.25$ \\
\hline & $\left(\delta^{18} \mathbf{O} \%\right)$ & $( \pm 0.7)$ & $( \pm 0.09)$ & $( \pm 0.13)$ \\
\hline & $\mathbf{T A}$ & $2200-2180(2188)$ & $2310-2320-2400$ & $2240-2280$ \\
\hline & $(\mu \mathrm{mol} / \mathrm{kg})$ & $( \pm 50)$ & $( \pm 14)$ & $( \pm 45)$ \\
\hline
\end{tabular}

Definition of parent-water masses based on available variables: temperature (T), practical salinity

$\left(\mathbf{S}_{P}\right)$, nitrate $\left(\mathbf{N O}_{3}{ }^{-}\right)$, soluble reactive phosphate $(\mathbf{S R P})$, dissolved silicate $(\mathbf{d S i})$ and dissolved oxygen $\left(\mathbf{O}_{2}\right)$ concentrations, stable oxygen isotopic composition of water $\left(\delta^{18} \mathbf{O}\left(\mathrm{H}_{2} \mathrm{O}\right)\right)$ and total alkalinity (TA). For each water mass and variable, the range of values used in the definition is given in the first row and the corresponding standard deviation of data around the definition (spread around black lines in Fig. 3b-c) in the second row. The range of values are chosen based on property-salinity diagrams (see Fig. 3 for two examples). The NACW definition consists of three water types, given the v-shape of the property-salinity diagrams (see Fig. 3c). For the CIL, a single-value definition (see Section 2.7) is also given in parentheses and is obtained from the mean value of observations.

The definition of our three parent-water masses are kept constant throughout the whole eOMP analysis period (1970s to 2018). Previous studies showed that the oxygen content of NACW did not change significantly over the last 50 years (Stendardo \& Gruber, 2012), nor did nutrient concentrations during the 1980s (Garcia et al., 1998). Additionally, an analysis of historical data on the Labrador Shelf reveals no statistically significant trends in time series of dissolved oxygen and nutrient concentrations, salinity and temperature at any given station over the past 20 years (Fig. 4; no trend with p-value $<0.01)$. The historical data used to define the CIL also show no statistically significant trend over the 1995-2018 period (p-value $>0.01$ for all variables), and no significant difference between the 1970s and 2018 (Figures S9 and S10). We tested whether the observed small year-to-year variations in LCW properties (at most $\Delta O_{2} \sim 20 \mu \mathrm{mol} / \mathrm{kg}$; Fig. 4) would affect the eOMP results with a sensitivity analysis, by perturbing the water-mass definitions. We find that the observed variations induce at most a 5\% difference in the eOMP results for the LCW fraction, which is within the uncertainty of the method.

Figure 4: Time-stations plots of summer averages of (a) practical salinity, (b) temperature, (c) oxygen concentration, and (d) nitrate concentration for stations along the Seal Island section shown in Fig. 1, from the shore (left) to the open ocean (right). The thick black lines show the edge of the continental shelf, where the seafloor drops from $\sim 200 \mathrm{~m}$ to more than $1000 \mathrm{~m}$ deep. Data are corrected for vertical sampling biases (see section 2.3).

\subsection{Set-up}

The eOMP analysis is run from available observations below $100 \mathrm{~m}$ along the Laurentian Channel for each year. Results for per season runs are available in the supplementary material (Fig. S3). At Cabot Strait, enough variables are available to perform the eOMP analysis for 1969-1970 and 1995-2018.

This article is protected by copyright. All rights reserved. 
$\delta^{18} \mathrm{O}\left(\mathrm{H}_{2} \mathrm{O}\right)$ is a strongly conservative hence reliable tracer, but is absent from the BioChem dataset. Hence, the analysis is run separately on both observational datasets (BioChem and Coriolis) and the results of each analysis are combined. To maintain an overdetermined system of equations in the eOMP, the number of water types has to be smaller than the number of variables (see Section 2.7). To meet this requirement, the eOMP analysis is run separately for the densest and shallowest parts of the three-water type NACW definition (Table 1), and we use a single-value definition for the CIL (see Table 1) in years for which alkalinity and $\delta^{18} O$ data are missing (see Table S1 for a summary of the runs for each year).

\subsection{Method: oxygen budget}

While the contribution of the CIL is important for the intermediate waters of the Laurentian Channel (100-150 m depth), the deep waters (below $150 \mathrm{~m}$ ) are composed almost exclusively of a mixture of LCW and NACW (see Section 3.1). Provided deep waters do not mix with surface or intermediate waters, oxygen concentrations in the deep waters at the head of the Laurentian Channel can be expressed as,

$$
O_{2}^{\text {head }}=f_{L C W} O_{2}^{L C W}+\left(1-f_{L C W}\right) O_{2}^{N A C W}-O U^{N A}-O U^{L C}
$$

where $\mathrm{O}_{2}$ is the oxygen concentration, $\mathrm{f}_{\mathrm{LCW}}$ is the relative contribution of LCW to the deep waters and $O U$ is the oxygen utilization divided in two terms: $O U$ from the definition sites of parent water masses in the North Atlantic (Fig. 3a) to Cabot Strait ( $\mathrm{OU}^{\mathrm{NA}}$ ), and during the transit along the Laurentian Channel from Cabot Strait to the head of the channel $\left(O U^{L C}\right)$. The change in oxygen concentration at the head of the channel between two different times, $\Delta O_{2}^{\text {head }}$, can be expressed as

$$
\Delta O_{2}^{\text {head }}=\underbrace{\Delta f_{L C W} O_{2}^{L C W}-\Delta f_{L C W} O_{2}^{N A C W}}_{\text {Change in LCW:NACW ratio }}-\underbrace{\Delta O U^{N A}}_{O_{2} \text { consumption in NA }}-\underbrace{\Delta O U^{L C}}_{\text {Biogeo change along LC }}
$$

Eq. 8 can be used to partition the deoxygenation observed at the head of the Laurentian Channel ( $\Delta \mathrm{O}_{2}^{\text {head }}$ ) into its different causes. Hereafter, $\Delta$ always refers to a change between two set times. The first two terms on the right hand-side of Eq. 8 represent the response of oxygen concentrations to changes in the relative contributions of LCW and NACW to the Laurentian Channel, while the third and fourth terms represent the response of oxygen concentrations to changes in respiration/photosynthesis in the North Atlantic (NA) and in the Laurentian Channel (LC), respectively. $\Delta O_{2}^{\text {head }}$ is computed from observations in the zone of the oxygen minimum near the head of the Laurentian Channel. The first and second terms on the right-hand side of Eq. 8 are computed using the LCW fractions at Cabot Strait provided by the eOMP analysis and the mean oxygen concentrations of the parent-water masses (Table 1). Oxygen utilization (OU ) is a secondary output of the eOMP analysis, derived from the change in the semi-conservative variable oxygen between the parent-water mass definition region and the site of observations ( $\Delta K$ in Eq. 1). The third and fourth terms are computed from this output, $\triangle O U^{N A}$ from the change in $O U$ in the North Atlantic, and $\triangle O U^{L C}$ from the change in $O U$ in the Laurentian Channel taking into account a transit time of 2 years (Bugden, 1991).

As temperature affects the rates of organic matter remineralization and oxygen utilization, we can further partition $\triangle O U$ into contributions from temperature change and from eutrophication:

$$
\Delta O U=\Delta O U_{\Delta T}+\Delta O U_{\text {eutroph }}
$$

We apply this partitioning only to the Laurentian Channel. The temperature dependence of the bacterial respiration rate is commonly expressed, for two temperatures $T_{1}$ to $T_{2}$, using the empirical change relative to a $10^{\circ} \mathrm{C}$ variation, $Q_{10}$ :

This article is protected by copyright. All rights reserved. 
$Q_{10}=\frac{R}{2}_{R_{1}}^{\left(\frac{10}{T_{2}-T_{1}}\right)}$

where $\mathrm{R}_{1}$ and $R_{2}$ are the rates of a given biological process at temperatures $T_{1}$ and $\mathrm{T}_{2}$, here oxygen utilization rates $(O U R)$ such that $O U R \times \Delta t=O U$ for a time interval $\Delta \mathrm{t}$. Typically, $1.8<Q_{10}<3.3$ (Genovesi et al., 2011; Bailey \& Ollis, 1986). Hence,

$$
\Delta O U_{\Delta T}^{L C}=O U_{T=T_{1}}\left[1-\exp \left(\frac{\Delta T}{10} \ln Q_{10}\right)\right]
$$

and the balance is attributed to eutrophication as

$$
\Delta O U_{\text {eutroph }}^{L C}=O U_{T=T_{2}}-\Delta O U_{\Delta T}^{L C}
$$

where $O U_{T=T_{i}}$ is the $O U$ at temperatures $\mathrm{T}_{\mathrm{i}}$. We obtain $\Delta \mathrm{T}$ from averaging observations along isopycnals in the region near Cabot Strait (Fig. S6).

\section{Results}

\subsection{Evolution of the origin of deep waters in the Laurentian Channel}

The eOMP analysis provides the fractions of LCW, NACW and CIL that make up the waters below $100 \mathrm{~m}$ in the Laurentian Channel between the head of the channel and Cabot Strait (dotted line on Fig. 1). In agreement with the traditional description of the system (Dickie \& Trites, 1983), the CIL dominates the composition of the water column between $100 \mathrm{~m}$ and $150 \mathrm{~m}$ while waters of North Atlantic origin (LCW and NACW) compose the waters below (Fig. 5). The eOMP analysis reproduces the uniform stratification along the channel and the relaxation of that stratification as we approach the head of the channel.

The exact distribution of LCW and NACW fractions in the water column has not been previously described. Here, we find that waters between $150 \mathrm{~m}$ and $300 \mathrm{~m}$ are fed at $\sim 75 \%$ by the NACW, while below $300 \mathrm{~m}$ the LCW predominate, contributing 50-60\% (Fig. 5). NACW and LCW partially mix vertically as they flow towards the head of the channel (Fig. 5 and Fig. S3). This vertical distribution is different than the one obtained from a T-S diagram analysis (see supplementary material S1 and Fig. S1), which implies that diapycnal mixing contributes to the mixing of LCW and NACW.

Figure 5: Transects along the Laurentian Channel (dashed grey line in Fig. 1) of the contribution (fraction) of LCW, NACW and CIL to the waters (left), as well as oxygen utilization (OU, right). Results are obtained from the eOMP analysis and presented here for years with a good data coverage. The top $100 \mathrm{~m}$ is blank (and top $150 \mathrm{~m}$ in 1969) as the eOMP is not run near the surface (see Section 2.9). White diamonds show the depths/locations for which data are available and thus where the eOMP analysis is run. Results from the eOMP analysis (colors) are interpolated linearly. Grey lines show the $1027.0,1027.3$ and $1027.5 \mathrm{~kg} \mathrm{~m}^{-3}$ isopycnals. The oxygen minimum lies approximately along the $1027.3 \mathrm{~kg} \mathrm{~m}^{-3}$ isopycnal. Distance is reported from Quebec City with the black triangles showing the position of important geographical features along the Laurentian Channel (see Fig. 2).

Given their different levels of oxygenation, the relative contributions of LCW and NACW to the deep waters $(>150 \mathrm{~m}$ ) of the Laurentian Channel modulate the oxygen concentrations in the channel. We examine the time series of these contributions in Figure 6 by averaging the fractions obtained from the eOMP analysis at and east of Cabot Strait (red box in Fig. 1) across each season and density bin. Overall, the NACW fraction increases with time at the expense of the LCW fraction, in agreement with conclusions of previous studies (Claret et al., 2018; Gilbert et al., 2005). The relative contributions of LCW and NACW vary with depth (Figs. 5 and 6). Thereafter, we focus the analysis

This article is protected by copyright. All rights reserved. 
on the $1027.30 \mathrm{~kg} \mathrm{~m}^{-3}$ isopycnal that lies close to the oxygen minimum (Fig. 2a). At that depth, the relative contribution of NACW increased from $\sim 40 \%$ in 1970 to $\sim 60 \%$ in 1997 , and to $\sim 80 \%$ in 2018.

The contribution of the CIL to the deep waters remains small $(<0.1$ fraction) throughout the time series (not shown). Yet, in 2016 and 2017 we find a deepening of CIL of $\sim 20 \mathrm{~m}$. The 2016 and 2017 results are associated with very large uncertainties and hence a low reliability due to the scarcity of data. Because the contribution of the CIL to the deep waters is small, and because the increase in CIL contribution is uncertain, limited in time, and below the uncertainties of the oxygen budget ( $<5 \mu \mathrm{mol} \mathrm{kg}^{-1}$ ), we do not include the contribution of the CIL to the oxygen budget. The relatively constant contribution of the CIL to the deep waters implies that vertical mixing rates along the Laurentian Channel did not vary significantly over the study period.

The increase in the NACW fraction is not continuous. From the late 1990s to 2008, the NACW contribution to the deep waters is statistically invariant (Fig. 6). Between 2008 and 2018, it shows a statistically significant increase of $0.02 \mathrm{yr}^{-1}$ (according to a student t-test, $\mathrm{p}$-value $<0.001$ ). In 2016, the NACW fraction reached its highest contribution over the whole record (concurrently, the LCW reached its lowest contribution). A comparison with the NACW contribution based on physical properties (supplementary material S1 and Fig. S1), for which data goes back to the 1930s, suggests that this value represents a historical maximum. This maximum in the contribution of salty NACW precedes a strong salinity anomaly observed in 2017 in the Gulf of Maine (Grodsky et al., 2018). This high salinity event supports our results, since the Laurentian Channel and the Gulf of Maine are both fed by the same Slope waters.

Figure 6: Time series of LCW (top) and NACW (bottom) relative contributions (fractions) to the deep waters at Cabot Strait, along the 1027.30 (blue) and $1027.50 \mathrm{~kg} \mathrm{~m}^{-3}$ (red) isopycnals. Each point is the average of data points in the vicinity of Cabot Strait (red box in Fig. 1). The significant trends from 2008 to 2018 are shown in grey (p-value $=0.0002$ along both isopycnals), and the nonsignificant trends from 1995 to 2008 by a dotted light grey (p-value $>0.1$ ). Error bars represent the sum of the standard deviation associated with averaging and the systematic 5\% error of the eOMP analysis (see section 2). Data are available for early 1970s and from 1995 to 2018.

\subsection{Biogeochemical changes}

Here, we examine the contribution of biogeochemical changes to the oxygen decline observed in the St. Lawrence Estuarine System. The eOMP analysis provides an observation-based quantification of the change in biogeochemical variables (see Section 2.10), expressed as oxygen utilization ( $O U$, right panel on Fig. 5). Results reveal that the mixture of LCW and NACW that enters the Gulf of St. Lawrence at Cabot Strait along the $1027.30 \mathrm{~kg} \mathrm{~m}^{-3}$ isopycnal has lost about $50 \mu \mathrm{mol} \mathrm{kg}^{-1}$ of oxygen compared to the parent-water mass definitions. This amount goes from $30 \pm 20 \mu \mathrm{mol} \mathrm{kg}^{-1}$ in the 1970 s, to close to $50 \pm 20 \mu \mathrm{mol} \mathrm{kg}^{-1}$ in the 1995 to 2010 period, and $41 \pm 16 \mu \mathrm{mol} \mathrm{kg}^{-1}$ from 2010 to 2018 (blue in Fig. 7c). These variations imply changes in biological activity in the North Atlantic over time.

The oxygen utilization along the transit of deep waters from Cabot Strait to the head of the Laurentian Channel $\left(O U^{L C}=O U^{\text {Cabot }}-O U^{\text {head }}\right)$ has been relatively invariant at $135( \pm 20) \mu \mathrm{mol} \mathrm{kg}^{-1}$ over the last 20 years (black in Fig. 7c). This value is supported by experimentally measured turbulent oxygen fluxes (see supplementary material S2). In addition, this value agrees well with that from Bourgault et al. (2012)'s model, which provides an estimate of the sum of the benthic and pelagic respiration along the channel of 63 or $125 \mu \mathrm{mol} \mathrm{kg}^{-1}$ depending if the transit time is taken to be 4 or 2 years, respectively. The $O U$ we obtain falls near the upper boundary of their estimate, suggesting that the transit time is closer to 2 years than 4 years.

\subsection{Partitioning of the oxygen decline}

This article is protected by copyright. All rights reserved. 
Between the early 1970s and 1995, deep waters at the head of the Laurentian Channel experienced a decline in oxygen concentrations of $50 \mu \mathrm{mol} \mathrm{kg}^{-1}$ (Fig. 7a). After some fluctuations from 1995 to 2008 , these deep waters lost an additional $22 \mu \mathrm{mol} \mathrm{kg}^{-1}$ from 2008 to 2018. Causes of this decline in oxygen concentrations can be examined with a simple oxygen budget. To do so, we partition the measured oxygen change at the entrance of the Gulf $\left(\Delta \mathrm{O}_{2}^{\text {Cabot }}\right)$ and at the head of the Laurentian Channel ( $\Delta O_{2}^{\text {head }}$ ) into contributions from physical and biogeochemical changes (Fig. 8 and Table S2, and Fig. 7 for time series of the drivers). As described in Equations 8 and 9, physical changes refer to the variations in the LCW and NACW relative contributions to deep waters, and biogeochemical changes refer to variations in oxygen utilization due to changes in nutrient cycling and increased temperature. Three periods are investigated: 1970-1995, 1995-2008 and 2008-2018.

The 1995 cutoff year marks the beginning of the continuity in data availability. Choosing 1995 as the end of the first period does not affect the results, since using any year within the 1995-2000 period results in the conclusion that biogeochemistry dominates the changes in oxygen concentrations since the 1970s. The choice of the 2008 cutoff maximizes the significance of the declining trend in the LCW contribution. Year-to-year LCW contributions can be computed from 1995 to 2018, with one additional value in the 1970s (Fig. 6). Given the lack of information on the evolution of oxygen concentrations and LCW contributions between 1970 and 1995, we can only consider the net difference between these two years. This difference yields valuable information on the long-term changes that occurred between the 1970s and the late 1990s, provided that 1970 is not an anomalous year. Water properties over years 1968-1972 and results of an eOMP analysis for the years 1969 and 1971 reveal that 1970 is representative of that period (Figures S7 and S8). Note that years 1968-1969 and 1971-1972 cannot be included in the LCW contribution time series (Fig. 6) because data are not available at Cabot Strait at the depth of the oxygen minimum.

Figure 7: Time series along the $1027.30 \mathrm{~kg} \mathrm{~m}^{-3}$ isopycnal of (a) oxygen concentration at Cabot Strait (blue) and at the head of the Laurentian Channel (black, same as in Fig. 7b), (b) LCW fraction at the entrance of the Gulf (Cabot Strait, same as Fig. 6), (c) in black, oxygen utilization between Cabot Strait and the head of the Laurentian Channel ( $\left.\mathrm{OU}^{\text {Cabot }}-\mathrm{OU}^{\text {head }}\right)$ and, in blue, oxygen utilization between the parent waters initial location in the North Atlantic and Cabot Strait $\left(O U^{\text {Cabot }}\right)$, as obtained from the eOMP analysis, and (d) net anthropogenic nitrogen input to the St. Lawrence watershed, reproduced from Goyette et al. (2016). Error bars in (b) and (c) show the sum of the systematic error in the eOMP analysis (5\%) and the standard deviation associated with averaging. $O U$ is not available at the head of the Laurentian Channel in the 1970s due to the lack of nutrient data. Hence, oxygen utilization in the 1970s (black dot in panel c) is estimated from the loss of oxygen from Cabot Strait to the head of the Laurentian Channel ( $\left.\mathrm{O}_{2}^{\text {head }}-\mathrm{O}_{2}^{\text {Cabot }}\right)$ considering a 2 to 4year transit time. $\mathrm{O}_{2}^{\text {head }}-\mathrm{O}_{2}^{\text {Cabot }}$ does not directly yield the oxygen utilization during the transit, since vertical mixing brings oxygen from the oxygen-saturated surface waters to the deep waters of the Laurentian Channel. To calculate the 1970 estimate, we assume that the turbulent fluxes were invariant over the 4 to 7 -year transit time from the Atlantic to the head of the Laurentian Channel, in which case the difference in $O_{2}^{\text {head }}-O_{2}^{\text {Cabot }}$ between two times is equivalent to the $O U$.

Figure 8: Partitioning of the oxygen decline at the head of the Laurentian Channel ( $\Delta \mathrm{O}_{2}^{\text {head }}$, red bars) into its various contributions (multicolor bars, see Section 2.10 for details on the method), over the 1970-1995 and 2008-2018 time periods. Since oxygen concentrations and their various contributions do not vary in the 1995-2008 period, we do not plot the partitioning for that period. The contributions are grouped into those taking place within the Laurentian Channel and in the North Atlantic. Biogeochemical contributions to the oxygen decline are eutrophication within the Laurentian Channel (green; $\Delta \mathrm{OU}_{\text {eutro }}^{\mathrm{LC}}$; Eq. 9), increased oxygen consumption rate due to a rise in water temperature (orange, $\Delta O U_{\Delta T}^{L C}$; Eq. 9), and the change in oxygen consumption rates in the North Atlantic (yellow, $\triangle O U^{N A}$; Eq. 8). The one physical contribution to the oxygen decline is the change

This article is protected by copyright. All rights reserved. 
in the relative contributions of LCW and NACW (blue, $\Delta \mathrm{fO}_{2}^{\mathrm{LCW}}-\Delta \mathrm{fO}_{2}^{\mathrm{NACW}}$; Eq. 8). The observed oxygen decline and sum of contributions are not equal, but the difference falls within the uncertainties. Values are given in Table S2. The error bars correspond to the sum of the uncertainties of each variable used in the calculation of each term (see Table S2).

\section{0-1995}

Between 1970 and 1995, nearly half of the oxygen decline observed at the head of the Laurentian Channel is explained by an increase in biological oxygen demand during the transit of deep waters along the Laurentian Channel $\left(\triangle O U_{\text {eutro }}^{L C}+\Delta O U_{\Delta T}^{L C}=24 \mu \mathrm{mol} \mathrm{kg}^{-1}\right)$. The increase in eutrophication is substantiated by an increase in nutrient inputs to the St. Lawrence watershed over the same period (Fig. 7d, reproduced from Goyette et al., 2016), We focus on the nitrogen input because nitrate is the limiting nutrient in the Estuary and Gulf (Jutras et al., 2020). The increased oxygen utilization derived from the eOMP analysis is consistent with previous reports of increased organic matter flux and eutrophication (Thibodeau et al., 2006) as well as enhanced respiration rates due to increased bottomwater temperatures (Genovesi et al., 2011) in the St. Lawrence Estuary. The remaining half is due to a reduction in the oxygen content of waters entering the channel at Cabot Strait from the North Atlantic ( $\Delta \mathrm{O}_{2}^{\text {Cabot }}=-28 \mu \mathrm{mol} \mathrm{kg}^{-1}$ based on observations), most of which is due to a change in oxygen utilization along the path of the parent waters in the North Atlantic $\left(\Delta O U^{N A}=-20 \mu \mathrm{mol} \mathrm{kg}^{-1}\right)$, with a smaller contribution from the reduced contribution of LCW to the deep waters of the Laurentian Channel ( $\triangle f O_{2}^{L C W}-\triangle f O_{2}^{N A C W}=-14 \mu \mathrm{mol} \mathrm{kg}^{-1}, 25 \%$ of the total oxygen decline). The biologicallydriven oxygen loss within the Laurentian Channel is attributed at $80 \%$ to eutrophication $\left(\Delta O \mathrm{OU}_{\text {eutro }}^{\mathrm{LC}}\right)$, while the rest is ascribed to the increased metabolic activity resulting from the warming of the deep waters $\left(\triangle O U_{\Delta T}^{L C}\right)$.

\section{5-2008}

Over the 1995-2008 period, oxygen concentrations and LCW and NACW contributions to the deep waters at Cabot Strait do not show any statistically significant trend, but display relatively large fluctuations (Fig. 7a-b). The LCW fraction decreases slightly from 1995 to $\sim 2000$, then increases from 2000 to $\sim 2005$, before remaining relatively stable from 2005 to 2008 . The amplitude of the fluctuations in the LCW fraction is larger in the deepest waters $\left(\sim 0.23\right.$ at $1027.5 \mathrm{~kg} \mathrm{~m}^{3}$ vs $\sim 0.13$ at $1027.3 \mathrm{~kg} \mathrm{~m}^{3}$, Fig. 6).

From 1995 to 2018, oxygen utilization within the Laurentian Channel and in the North Atlantic remain relatively stable (Fig. 7c). This stabilization in oxygen utilization is consistent with a levelling off of the nitrogen input to the St. Lawrence watershed over the same period (Fig. 7d, reproduced from Goyette et al., 2016). A change in the transit velocity of deep waters could also influence the biological oxygen demand within the Laurentian Channel, but that hypothesis was refuted by Bugden (1991). The increase in bottom-water temperatures since 1995 ( $+1.02^{\circ} \mathrm{C}$, Fig. S6) would have resulted in a small increase in oxygen utilization, but the uncertainties in the $O U$ time series are larger than the expected increase.

\section{8-2018}

Over the 2008-2018 period, between 75 and 100\% of the oxygen decline at the head of the Laurentian Channel is due to a reduction in the contribution of LCW to the deep waters of the Laurentian Channel $\left(\triangle f O_{2}^{L C W}-\triangle f O_{2}^{N A C W}=-22 \mu \mathrm{mol} \mathrm{kg}^{-1}\right.$, the percentages are presented as a range, calculated relative to the measured change in oxygen concentrations and to the sum of the contributions computed in Eq. 8). The reduction in the LCW fraction represents a $200 \%$ increase in the oxygen loss rate at Cabot Strait compared to the 1970-1995 period. In contrast to the 1970-1995 period, oxygen utilization (Fig. 7c) remains stable in the North Atlantic from 2008 to $2018\left(\Delta \mathrm{OU}^{\mathrm{NA}}=-1 \mu \mathrm{mol} \mathrm{kg}^{-1}\right.$ ). What caused the variations in oxygen utilization in the North Atlantic between the two time periods

This article is protected by copyright. All rights reserved. 
is unknown. Oxygen utilization along the Laurentian Channel also remains relatively stable or decreased slightly from 2008 to $2018\left(\Delta O U_{\text {eutro }}^{L C}+\Delta O U_{\Delta T}^{L C}\right)$.

\subsection{Drivers of the change in parent-water mass inflow to the St. Lawrence}

Our analysis reveals a shift to a gradual decrease of the relative contribution of LCW to deep waters of the St. Lawrence Estuarine System starting in 2008 (Fig. 6). In the following, we focus on the $\mathrm{LCW}$ fraction as the timeseries of the NACW and LCW fractions mirror each other. Here, we investigate the possible controls of the LCW and NACW fractions by calculating correlations between the fraction of LCW at the $1027.30 \mathrm{~kg} \mathrm{~m}^{-3}$ isopycnal at Cabot Strait and indices of the main drivers of ocean and climate variability in the North Atlantic between 1995 and 2018 (Fig. 9).

The predominance of NACW over LCW in the Cold Slope Waters is thought to be associated with a northern shift of the Gulf Stream and a concurrent retreat of the Labrador Current (Townsend et al., 2015), likely driven by the contraction of the subpolar gyre under a positive phase of the North Atlantic Oscillation (NAO) or a slow-down of the AMOC driven by climate change (e.g., Claret et al., 2018). We find no significant correlation between the LCW fraction at the mouth of the Laurentian Channel and the Gulf Stream transport index ( $r=-0.16$; Fig. 9) or the Gulf Stream Front position $(\mid \mathrm{r}$ $K 0.3$, not shown), regardless of the metrics used for the front position. We also find no statistically significant correlation between the LCW fraction and the NAO index over the late 1990s to 2018 period (Fig. 9). Previous studies showed that, until the 1990s or 2000s, the NAO was correlated with water properties on the shelf, but that this relation had weakened since (Peterson et al., 2017; Townsend et al., 2015). Whereas the NAO influences large-scale winds in the North Atlantic, local high-frequency winds can also affect circulation near the shelf, and we find that winds blowing eastward on the outer Labrador Shelf favor a low contribution of LCW to the Laurentian Channel (see supplementary material S3 and Fig. S2).

In contrast, the LCW fraction is strongly and positively correlated $(\mathrm{r}=0.81)$ with the volume transport of the Scotian shelf-break current (Fig. 9). The beginning of the rapid decline of the LCW fraction identified in 2008 is concurrent with the beginning of a $\sim 10$-year decline in that transport. The Scotian shelf-break current is formed from the portion of the main branch of the Labrador Current that hugs the shelf-break downstream of the Grand Banks. Hence, the correlation between the LCW fraction and the volume transport of the main branch of the Labrador Current is significant but smaller than that with the volume transport of the Scotian shelf-break current ( $r=-0.61)$. The negative correlation is consistent with the Scotian shelf-break current transport being anti-correlated with the strength of the main branch of the Labrador Current (Cyr et al., 2020; Han et al., 2014). The portion of the main branch of the Labrador Current that does not feed the Scotian shelf-break current is deflected towards the open ocean to supply the North Atlantic Current, the extension of the Gulf Stream (Fig. 1). The main branch of the Labrador Current also forms the western branch of the subpolar gyre (Fig. 1). Accordingly, we find a significant correlation between the LCW fraction at Cabot Strait and the subpolar gyre index (SPGi, $r=0.40$; Fig. 9). The contraction and extension of the subpolar gyre affects the offshore Labrador Current, but what controls the fate of Labrador Current waters at the Tail of the Grand Banks is unknown (Holliday et al., 2020). The positive correlation between the LCW fraction at Cabot Strait and the strength of the subpolar gyre obtained here suggests that when the gyre index is positive, more LCW turn west to feed Slope waters, and when the index is negative, more waters are diverted towards the open Atlantic Ocean. For all the above indices, the correlation is highest for a zero time lag. Closer to the coast, the Shelf-Slope Front isolates Slope waters from coastal (shelf) waters. Its position is determined by the extent of LCW intrusions along the slope, and hence has been shown to influence water properties on the shelf (Austin et al., 2019) and in the Laurentian Channel (Bugden, 1991). A significant correlation is found between the LCW fraction and the latitude of the Shelf-Slope Front $(r=-0.74$, Fig. 9), with a maximum reached with a lag of one year.

The indices presented above are not independent. The phase of the NAO influences the strength of the subpolar gyre, the western boundary of the subpolar gyre forms the main branch of the Labrador Current, and that branch feeds the Scotian shelf-break current. The latter, as we showed, correlates

This article is protected by copyright. All rights reserved. 
with the intrusions of LCW along the continental slope and the position of the Shelf-Slope Front. The magnitude of the correlations between the LCW fraction and the various indices investigated reflect these causal relationships. Overall, our results point to the Labrador Current, through its extension on the Scotian shelf, as the main determinant of the LCW:NACW ratio in the deep waters of the Laurentian Channel.

Figure 9: From top to bottom: time series of the LCW fraction along the $1027.3 \mathrm{~kg} \mathrm{~m}^{-3}$ isopycnal at Cabot Strait (dark blue, same top panel of Fig. 6), Scotian shelf-break current (SSBC) transport index (magenta), subpolar gyre index (SPGi, orange), Gulf Stream index (black), Shelf-Slope Front mean latitude (light grey, and moving average in light blue), and NAO index (green/red). Details regarding each index are provided in Section 2.1. Correlation coefficients (CC) and associated p-value between the LCW fraction and each climate index are given below each curve.

\section{Discussion and conclusions}

The causes of five decades of oxygen decline in the deep waters of the Lower St. Lawrence Estuary are examined using an extended Optimum Multiparameter (eOMP) analysis. This method is applied to a continuous time series of in-situ measurements of physical and biogeochemical variables taken along the Laurentian Channel in the Gulf and Estuary of the St. Lawrence since 1995, with additional data from the 1970s. The use of the eOMP method is justified by evidences of diapycnal mixing along the path of the deep waters. We find that the decrease in oxygen concentrations in the Lower Estuary is driven by a combination of physical and biogeochemical changes, but that the relative importance of these drivers to the observed oxygen decrease has varied significantly over the last 50 years (Fig. 10). Between the 1970s and late 1990s, biogeochemical changes explain 85-90\% of the 1.7 ( $\pm 0.3) \mu \mathrm{mol} \mathrm{kg}^{-1}$ year $^{-1}$ oxygen decline, through an increase in oxygen utilization rates in the deep waters of the Laurentian Channel and in the North Atlantic (Fig. 7). Between 2008 and 2018, circulation changes explain $75-100 \%$ of the $2.2( \pm 1.0) \mu \mathrm{mol} \mathrm{kg}^{-1}$ year ${ }^{-1}$ oxygen decline, through the increased inflow of oxygen-poor North Atlantic Central Waters (NACW) into the Laurentian Channel at the expense of oxygen-rich Labrador Current Waters (LCW, Fig. 6). In 2016, the relative contribution of LCW reached a record low since the beginning of measurements in the 1930s. The relative influence of biogeochemical and circulation changes to the oxygen decline differs from that found by Gilbert et al. (2005), probably due to their use of the T-S diagram mixing method that overestimates the relative contribution of LCW at the depth of the oxygen minimum (see supplementary material S1) and to the different time periods used in each study.

Modelling studies have attributed the recent changes in the relative contributions of LCW and NACW to deep waters entering the St. Lawrence Estuarine System to a slow-down of the AMOC driven by climate change (e.g., Claret et al., 2018). Our observation-based analysis shows that a low frequency variability (multi-year) dominates the time series of the LCW fraction, overlying a weak inter-annual and seasonal variability (see Fig. 6 and Fig. S3). Whereas the AMOC slow-down expected under anthropogenic climate change would cause a decrease in the LCW contribution to the deep waters, the LCW contribution was stable from 1995 to 2008 and decreased at a rate of -0.02 -LCW fraction $\mathrm{yr}^{-1}$ from 2008 to 2018, which suggests a predominance of natural variability over the past decades. A longer time series would be required to determine the nature of the low frequency signal detected in the LCW fraction time series, and models could be used to investigate the role of natural variability in the fluctuations of the LCW inflow.

The variability in the relative contributions of LCW to the deep waters of the Laurentian Channel is found to be well correlated with the volume transport of the Scotian shelf-break Current, an extension of the main branch of the Labrador Current over the Scotian shelf. In contrast, the position and volume transport of the Gulf Stream are weakly correlated with the LCW fraction at the entrance of the channel. In the commonly used description of circulation in the region, anomalously warm (Peterson et al., 2017; Pershing et al., 2001; Loder et al., 2001) and poorly oxygenated shelf waters (Claret et al., 2018) are attributed to a retreat of the Labrador Current and a concurrent northward shift of the Gulf Stream leading to an increased inflow of subtropical waters. Our analyses suggest that the Labrador Current, rather than the Gulf Stream, controls the variability of North Atlantic waters inflow

This article is protected by copyright. All rights reserved. 
to the St. Lawrence Estuarine System and of the Cold Slope waters that feed that system (Hameed \& Piontkovski, 2004; Rossby \& Benway, 2000). In other words, through the Scotian shelf-break Current, the Labrador Current would be able to push the Gulf Stream away from the continental slope, and the Gulf Stream would not be able to block the LCW intrusions from flowing south along the slope. The strength of the Scotian shelf-break Current is modulated by how much Labrador Current waters are diverted towards the open ocean when they flow around the Grand Banks (Holliday et al., 2020). Additional work is required to identify what controls the variability of the Labrador Current. Such an understanding is critical to improve our ability to predict the oxygen decline in the St. Lawrence Estuarine system and the composition of Cold Slope waters.

Figure 10: Summary of the contributions of physical and biogeochemical causes to the oxygen decline at the head of the Laurentian Channel, for two periods of time (1970-1995 / 2008-2018). The contributions are expressed as range of percentages, calculated relative to the observed change and to the sum of causes (see Fig. 8). The names and colors of the causes are the same as in Fig. 8.

\section{Open Research}

The two main datasets for this research are the BioChem database compiled by the Department of Fisheries and Oceans Canada and the Coriolis dataset compiled by Alfonso Mucci's research group. The BioChem database can be accessed at https://www.dfo-mpo.gc.ca/science/datadonnees/biochem/index-eng.html and the Coriolis dataset can be accessed at on the Open Science Framework data repository at osf.io/576tj/ and cited using the following DOI: 10.17605/OSF.IO/576TJ. Additional dataset like climate indices are available at the websites indicated in Section 2.1. NCEP Reanalysis data were provided by the NOAA/OAR/ESRL PSD, Boulder, Colorado, USA, from their website at https: //www.esrl.noaa.gov/psd.

Acknowledgments This study was funded by a Regroupement Stratégique grant from the Fonds de Recherche du Québec - Nature et Technologies (FRQNT) to GEOTOP and Québec-Océan, by the Department of Fisheries and Oceans Canada through the Ocean and Freshwater Science Contribution Program (OFSCP) to the St. Lawrence Ecosystem Health Research and Observation Network (SECO), and by the Natural Sciences and Engineering Research Council of Canada (NSERC) through Discovery grants to A.M. and NSERC Accelerator Supplements to C.O.D. M.J. acknowledges SECO, the Department of Earth and Planetary Sciences at McGill, Hydro-Québec, NSERC and the FQRNT for financial support in the form of stipends, scholarships and assistantships, and Québec-Océan for scientific support. We thank Diane Lavoie for useful discussions and Jean-Olivier Goyette for sharing his results. We also thank three anonymous reviewers whose constructive comments greatly improved this manuscript.

\section{References}

Austin, A. M., Bisagni, J. J., \& Schmidt, A. (2019). Inter-annual variability of shelf water volume on the northeastern Canadian and United States continental shelf, 19732013.Continental Shelf Research, 187(August), 103962. Retrieved from https://doi.org/10.1016/j.csr.2019.103962 doi: 10.1016/j.csr.2019.103962

Bailey, J. E., \& Ollis, D. F. (1986). Fundamentals of Biochemical Engineering (2 ${ }^{\text {nde }}$ d.). New York: McGraw-Hill.

Bindoff, N. L., Cheung, W. W. L., \& Kairo, J. G. (2019). Chap. 5: Changing Oean, Marine Ecosystems, and Dependent Communities (Tech. Rep.). Retrieved from https://www.ipcc.ch/srocc/download-report/ doi: https://www.ipcc.ch/ report/sroce/

Bourgault, D., Cyr, F., Galbraith, P. S., \& Pelletier, E. (2012). Relative importance of pelagic and sediment respiration in causing hypoxia in a deep estuary. Journal of Geophysical Research: Oceans, 117(8), 1-13. doi: 10.1029/2012JC007902

This article is protected by copyright. All rights reserved. 
Boyer, T., Antonov, J. I., Baranova, O. K., Coleman, C., Garcia, H. E., Grodsky S. A., ... Zweng, M. M. (2013). World Ocean Database 2013.

Breitburg, D., Levin, L. A., Oschlies, A., Gregoire, M., Chavez, F. P., Conley, D. J., ... Isensee, K. (2018). Declining oxygen in the global ocean and coastal waters. Science, 359(eaam7240).

Brickman, D., Wang, Z., \& DeTracey, B. (2016). Variability of Current Streams in Atlantic Canadian Waters: A Model Study. Atmosphere - Ocean, 54 (3), 218-229. doi:

10.1080/07055900.2015.1094026

Bugden, G. L. (1991). Changes in the temperature-salinity characteristics of the deeper waters of the Gulf of St. Lawrence over the past several decades. The Gulf of St. Lawrence: small ocean or big estuary, 113, 139-147.

Caesar, L., Rahmstorf, S., Robinson, A., Feulner, G., \& Saba, V. (2018). Observed fingerprint of a weakening Atlantic Ocean overturning circulation. Nature, 556, 191-196. doi: 10.1038/s41586-0180006-5

Chabot, D., \& Dutil, J. D. (1999). Reduced growth of Atlantic cod in non-lethal hypoxic conditions. Journal of Fish Biology, 55(3), 472-491. doi: 10.1006/jfbi .1999.1005

Churchill, J. H., Levine, E. R., Connors, D. N., \& Cornillon, P. C. (1993). Mixing of shelf, slope and Gulf Stream water over the continental slope of the Middle Atlantic Bight. Deep-Sea Research Part 1, 40(5), 1063-1085. doi: 10.1016/0967-0637(93)90090-P

Claret, M., Galbraith, E. D., Palter, J. B., Bianchi, D., Fennel, K., Gilbert, D., \& Dunne, J. P. (2018). Rapid coastal deoxygenation due to ocean circulation shift in the northwest Atlantic. Nature Climate Change, 8. Retrieved from http://www.nature.com/articles/s41558-018-0263-1 doi: 10.1038/s41558-018-0263-1

Cyr, F., Colbourne, E., Galbraith, P. S., Gibb, O., Snook, S., Bishop, C., . . Sen- ciall, D. (2020). Physical Oceanographic Conditions on the Newfoundland and Labrador Shelf during 2018. DFO Can.Sci. Advis. Sec. Res. Doc., 48 pp. Retrieved from http://waves-vagues.dfompo.gc.ca/Library/362068.pdf D'Amours,

D. (1993). The distribution of cod (Qadus morhua) in relation to tem-perature and oxygen level in the Gulf of St. Lawrence. Fisheries Oceanography, 2(1), 24-29. doi: 10.1111/j.13652419.1993.tb00009.x

Devine, L., Kennedy, M. K., St. Pierre, I., Lafleur, C., Ouellet, M., \& Bond, S. (2014). BioChem: the Fisheries and Oceans Canada Database for Biological and Chemical Data (Tech. Rep.). Fisheries and Oceans Canada. DFO. (2019). BioChem: database of biological and chemical oceanographic data. Retrieved 2018-12-01, from http://www.dfo-mpo.gc.ca/science/datadonnees/biochem/index-eng.html

Dickie, L., \& Trites, R. (1983). The Gulf of St. Lawrence (B. Ketchum, Ed.). Elsevier.

Dinauer, A., \& Mucci, A. (2017). Spatial variability in surface-water pCO2 and gas exchange in the world's largest semi-enclosed estuarine system: St. Lawrence Estuary (Canada). Biogeosciences, 14 (13), 3221-3237. doi: 10.5194/bg-14-3221-2017

Drinkwater, K. F. (1994). Climatic Data for the Northwest Atlantic: The Position of the Shelf (Tech. Rep.). Dartmouth, NS: Canada. Dept. of Fisheries and Oceans. Scotia-Fundy Region. Physical and Chemical Sciences Branch.

Drinkwater, K. F., Mountain, D. B., \& A., H. (1998). Recent Changes in the Hydrography of the Scotian Shelf and Gulf of Maine - A Return to Conditions of the 1960s? Northwest Atlantic Fisheries Organization(1993), 1-16. doi: N5318

Dupont-Prinet, A., Pillet, M., Chabot, D., Hansen, T., Tremblay, R., \& Audet, C. (2013). Northern shrimp (Pandalus borealis) oxygen consumption and metabolic enzyme activities are severely constrained by hypoxia in the Estuary and Gulf of St. Lawrence. Journal of Experimental Marine Biology and Ecology, 448, 298-307. doi: 10.1016/j.jembe.2013.07.019

This article is protected by copyright. All rights reserved. 
Emery, W. J., \& Meincke, J. (1986). Global water masses: summary and review. Oceanologica Acta, 9(4), 383-391.

Environment and Climate Change Canada. (2018). Canadian Environmental Sustainability Indicators: Nutrients in the St. Lawrence River. www.canada.ca/en/environment-climatechange/services/environmental- indicators/nutrients-st-lawrence-river.html. Retrieved e2020, from www.canada.ca/en/environment-climate-change/services/environmental indicators/nutrients-st-lawrence-river.html doi: 10.1038/ngeo2002

Fratantoni, P. S., \& Pickart, R. S. (2007). The western North Atlantic shelfbreak current system in summer. Journal of Physical Oceanography, 37(10), 25092533. doi: 10.1175/JPO3123.1

Galbraith, P. S. (2006). Winter water masses in the Gulf of St. Lawrence. Journal of Geophysical Research: Oceans, 111 (6). doi: 10.1029/2005JC003159

Gangopadhyay, A., Gawarkiewicz, G., Silva, E. N. S., Monim, M., \& Clark, J. (2019). An Observed Regime Shift in the Formation of Warm Core Rings from the Gulf Stream. Scientific Reports, 9(1), 1-9. doi: 10.1038/ s41598-019-48661-9

Garcia, H. E., Cruzado, A., Gordon, L., \& Escanez, J. (1998). Decadal-scale chemical variability in the subtropical North Atlantic deduced from nutrient and oxygen data. Journal of Geophysical Research: Oceans, 103(C2), 2817-2830. Retrieved from http://doi.wiley.com/10.1029/97JC03037 doi: 10.1029/97JC03037

Gatien, M. G. (1976). A Study in the Slope Water Region South of Halifax. Journal of Fishery Research Board of Canada, 33, 2213-2217.

Gawarkiewicz, G., Todd, R. E., Zhang, W., Partida, J., Gangopadhyay, A., Monim, M. U. H., ... Dent, M. (2018). The changing nature of shelf-break exchange revealed by the OOI Pioneer Array. Oceanography, 31 (1), 60-70. doi: 10.5670/oceanog.2018.110

Genovesi, L., de Vernal, A., Thibodeau, B., Hillaire-Marcel, C., Mucci, A., \& Gilbert, D. (2011). Recent changes in bottom water oxygenation and temperature in the gulf of st. Lawrence: Micropaleontological and geo- chemical evidence. Limnology and Oceanography, 56(4), 13191329. doi: 10.4319/lo.2011.56.4.1319

Gilbert, D. (2004). Propagation of temperature signals along the northwest Atlantic continental shelf edge and into the Laurentian Channel. In Abstract, ices ciem annual science conference september (pp. 22-25).

Gilbert, D., \& Pettigrew, B. (1997). Interannual variability (1948-1994) of the CIL core temperature in the Gulf of St. Lawrence. Canadian Journal of Fisheries and Aquatic Sciences, 54 (S1), 57 67. doi: 10.1139/f96-160

Gilbert, D., Rabalais, N. N., Diaz, R. J., \& Zhang, J. (2010). Evidence for greater oxygen decline rates in the coastal ocean than in the open ocean. Biogeo-sciences, 7(7), 2283-2296. doi: 10.5194/bg7-2283-2010

Gilbert, D., Sundby, B., Gobeil, C., Mucci, A., \& Tremblay, G.-H. (2005). A seventy-two-year record of diminishing deep-water oxygen in the St. Lawrence estuary: The northwest Atlantic connection. Limnology and Oceanography, 50 (5), 1654-1666.

Gouretski, V. (2018). WOCE-Argo Global Hydrographic Climatology (WAGHC Version 1.0).

Goyette, J.-o., Bennett, E. M., Howarth, R. W., \& Maranger, R. (2016). Changes in anthropogenic nitrogen and phosphorus inputs to the St. Lawrence sub-basin over 110years and impacts on riverine export. Global Biogeochemical Cycles, 30, 1000-1014. doi: 10.1002/2016GB005384.Received

Greene, C. H., \& Pershing, A. J. (2003). The flip-side of the North Atlantic Oscillation and modal shifts in slope-water circulation patterns. Limnology and Oceanography, 48(1 I), 319-322. doi: 10.4319/lo.2003.48.1.0319

This article is protected by copyright. All rights reserved. 
Gregg, M. C., Winkel, D. W., MacKinnon, J. A., \& Lien, R. C. (1999). Mixing on Shelves and Slopes. In Aha hulikoa: Dynamics of oceanic internal gravity waves ii (pp. 35-41).

Grodsky, S. A., Reul, N., Chapron, B., Carton, J. A., \& Bryan, F. O. (2017). Interannual surface salinity on Northwest Atlantic shelf. Journal of Geophysical Research: Oceans, 122, 3638-3659. doi: 10.1002/2017JC012961.Received

Grodsky, S. A., Vandemark, D., Feng, H., \& Levin, J. (2018). Satellite detection of an unusual intrusion of salty slope water into a marginal sea: Using SMAP to monitor Gulf of Maine inflows. Remote Sensing of Environment, 217(June), 550-561. Retrieved from https://doi.org/10.1016/jrse.2018.09.004 doi: 10.1016/j.rse.2018.09.004

Hameed, S., \& Piontkovski, S. (2004). The dominant influence of the Icelandic Low on the position of the Gulf Stream northwall. Geophysical Research Letters , 31 (9), 1998-2001. doi: 10.1029/2004GL019561

Han, G., Chen, N., \& Ma, Z. (2014). Is there a north-south phase shift in the surface Labrador Current transport on the interannual-to-decadal scale? Journal of Geophysical Research: Oceans, 119(1), 276-287. doi: 10.1002/2013JC009102

Hatun, H., \& Chafik, L. (2018). On the Recent Ambiguity of the North Atlantic Subpolar Gyre Index. Journal of Geophysical Research: Oceans, 123(8), 5072-5076. doi: 10.1029/2018JC014101

Hedges, J. I., Baldock, J. A., Gelinas, Y., Lee, C., Peterson, M. L., \& Wakeham, S. G. (2002). The biochemical and elemental compositions of marine plankton: A NMR perspective. Marine Chemistry, 78(1), 47-63. doi: 10.1016/S0304-4203(02)00009-9

Herman, A. W., \& Denman, K. L. (1979). Intrusions and Vertical Mixing at the Shelf/Slope Water Front South of Nova Scotia. Journal of the Fisheries Research Board of Canada, 36(12), 1445-1453. doi: 10.1139/f79-211

Holliday, N. P., Bersch, M., Berx, B., Chafik, L., Cunningham, S., Florindo-Laopez, C., ... Yashayaev, I. (2020). Ocean circulation causes the largest freshening event for 120 years in eastern subpolar North Atlantic. Nature Communications , 11 (1). doi: 10.1038/s41467-020-14474-y

Hudon, C., Gagnon, P., Rondeau, M., Hebert, S., Gilbert, D., Hill, B., ... Starr, M. (2017). Hydrological and biological processes modulate carbon, nitrogen and phosphorus flux from the St. Lawrence River to its estuary (Quebec, Canada). Biogeochemistry, 135(3), 251-276.

Joyce, T. M., \& Zhang, R. (2010). On the Path of the Gulf Stream and the Atlantic Meridional Overturning Circulation. Journal of Climate, 23, 3146-3154. doi: 10.1175/2010JCLI3310.1

Jutras, M., Mucci, A., Sundby, B., Gratton, Y., \& Katsev, S. (2020). Nutrient cycling in the Lower St. Lawrence Estuary: Response to environmental perturbations. Estuarine, Coastal and Shelf Science, 239 .

Kalnay, E., Kanamitsu, M., Kistler, R., Collins, W., Deaven, D., Gandin, L., ... Others (1996). The NCEP/NCAR 40-year reanalysis project. Bulletin of the American meteorological Society, 77(3), 437-472.

Karstensen, J., \& Tomczak, M. (1998). Age determination of mixed water masses using CFC and oxygen data. Journal of Geophysical Research, 103(C9), 18599-18609.

Karstensen, J., \& Tomczak, M. (1999). OMP Analysis Package for MATLAB. Retrieved from omp.geomar.de/README.html

Klein, B., \& Tomczak, M. (1994). Identification of diapycnal mixing through optimum multiparameter analysis 2. Evidence for unidirectional diapycnal mixing in the front between North and South Atlantic Central Water. Journal of Geophysical Research, 99(C12), 275-280. doi: 10.1029/94jc01948

Loder, J. W., Petrie, B. D., \& Gawarkiewicz, G. (1998). The coastal ocean off northeastern North America: a large-scale view. In The sea (Vol. 11, pp. 105-133).

This article is protected by copyright. All rights reserved. 
Loder, J. W., Shore, J. A., Hannah, C. G., \& Petrie, B. D. (2001). Decadal-scale hydrographic and circulation variability in the Scotia - Maine region. Deep-Sea Research Part II: Topical Studies in Oceanography, 48(1-3), 3-35. doi: 10.1016/S0967-0645(00)00080-1

Lohmann, K., Drange, H., \& Bentsen, M. (2009). Response of the North Atlantic subpolar gyre to persistent North Atlantic oscillation like forcing. Climate Dynamics, 32, 273-285. doi:

10.1007/s00382-008-0467-6

Luo, Y., Prater, M. D., Durbin, E. G., \& Rothstein, L. M. (2006). Changes in the Northwest Atlantic circulation for the 1992-95 high NAO period from a numerical model. Continental Shelf Research, 26(14), 1617-1635. doi: 10.1016/j.csr.2006.05.006

Mitchell, M. R., Harrison, G., Paule, K., Gagne, A., Maillet, G., \& Strain, P. (2002). Atlantic Zonal Monitoring Program Sampling Protocol. Can. Tech. Rep. Hy-drogr. Ocean Sci, 223. Retrieved from ISSN0711-6764

Mountain, D. G. (2012). Labrador slope water entering the Gulf of Maine-response to the North Atlantic Oscillation. Continental Shelf Research, 47, 150-155. Retrieved from http://dx.doi.org/10.1016Zj.csr.2012.07.008 doi: 10.1016/j.csr.2012.07.008

Mucci, A., \& Jutras, M. (2020). Coriolis Hydrographic Dataset. Retrieved from osf.io/576tj/ doi: 10.17605/OSF.IO/576TJ

Nash, J. D., Kunze, E., Toole, J. M., \& Schmitt, R. W. (2004). Internal tide reflection and turbulent mixing on the continental slope. Journal of Physical Oceanography, 34 (5), 1117-1134. doi: 10.1175/1520-0485(2004)034(1117: ITRATM)2.0.CO;2

Pelegri, J. L., \& Csanady, G. T. (1994). Diapycnal mixing in western boundary currents. Journal of Geophysical Research, 99(C9), 18275-18304.

Perez-Hernandez, M. D., \& Joyce, T. M. (2014). Two modes of Gulf Stream variability revealed in the last two decades of satellite altimeter data. Journal of Physical Oceanography, 44 (1), 149-163. doi: 10.1175/JPO-D-13-0136.1

Pershing, A. J., Greene, C. H., Hannah, C., Sameoto, D., Head, E., Mountain, D. G., ... Durbin, T. (2001). Oceanographic Responses to Climate in the Northwest Atlantic. Oceanography, 14 (3), 76-82. doi: 10.1139/f93-270

Peterson, I., Greenan, B., Gilbert, D., \& Hebert, D. (2017). Variability and wind forcing of ocean temperature and thermal fronts in the Slope Water region of the Northwest Atlantic. Journal of Geophysical Research: Oceans, 122, 7325-7343. doi: 10.1002/2016JC012335.Received

Petrie, B. D. (2007). Does the North Atlantic Oscillation affect hydrographic properties on the Canadian Atlantic Continental Shelf? Atmosphere - Ocean, 45(3), 141-151. doi: 10.3137/ao.450302

Petrie, B. D., \& Drinkwater, K. F. (1993). Temperature and Salinity Variability on the Scotian Shelf and in the Gulf of Maine 1945-1990. , 98(C11), 20079-20089.

Pickart, R. S., McKee, T. K., Torres, D. J., \& Harrington, S. A. (1999). Mean Structure and Interannual Variability of the Slopewater System South of Newfoundland. Journal of Physical Oceanography, 29(10), 2541-2558. Retrieved from http://journals.ametsoc.org/doi/abs/10.1175/1520-0485 $\mathrm{A} 70$ \}281999\{V,\}29029\{\\%\}3C2541\{Y/,\}3AMSAIV0\{Y/,\}3E2.0.C0\{Y/,\}3B2 doi: 10.1175/15200485(1999)029 (2541:MSAIV0)2.0.C0;2

Rabalais, N. N., Cai, W. J., Carstensen, J., Conley, D. J., Fry, B., Hu, X., ... Zhang, J. (2014). Eutrophication-Driven Deoxygenation in the Coastal Ocean. Oceanography, 27(1), 171-183. doi: 10.5670/oceanog.2011.65

Rabalais, N. N., Diaz, R. J., Levin, L. A., Turner, R. E., Gilbert, D., \& Zhang, J. (2010).

Dynamics and distribution of natural and human-caused hypoxia. Biogeosciences, 7, 585-619.

This article is protected by copyright. All rights reserved. 
Rodrlguez-Santana, A., Pelegrl, J. L., Sangra, P., \& Marrero-DIaz, A. (1999). Di- apycnal mixing in Gulf Stream meanders. Journal of Geophysical Research: Oceans, 104 (C11), 2589125912. doi: $10.1029 / 1999$ jc900219

Rossby, T. (1999). On gyre interactions. Deep-Sea Research Pari II: Topical Studies in Oceanography, 46(1-2), 139-164. doi: 10.1016/S0967-0645(98)00095-2

Rossby, T., \& Benway, R. L. (2000). Slow variations in mean path of the Gulf Stream east of Cape Hatteras. Geophysical Research Letters, 27(1), 117-120. doi: 10.1029/1999GL002356

Schollaert, S. E., Rossby, T., \& Yoder, J. A. (2004). Gulf Stream cross-frontal exchange: Possible mechanisms to explain interannual variations in phyto- plankton chlorophyll in the Slope Sea during the SeaWiFS years. Deep-Sea Research Part II: Topical Studies in Oceanography, 51 (1-3), 173-188. doi: 10.1016/j.dsr2.2003.07.017

Stendardo, I., \& Gruber, N. (2012). Oxygen trends over five decades in the North Atlantic. Journal of Geophysical Research: Oceans, 117(11), 1-18. doi: 10 .1029/2012JC007909

Stouffer, R. J., Yin, J., Gregory, J., Dixon, K., \& Spelman, M. (2006). Investigating the Causes of the Response of the Thermohaline Circulation to Past and Future Climate Changes. Journal of Climate, 19, 1365-1387. doi: 10.1002/9781119115397.ch25

Taylor, A. H., \& Stephens, J. A. (1998). The North Atlantic Oscillation and the latitude of the Gulf Stream. Tellus, Series A: Dynamic Meteorology and Oceanography, 50(1), 134-142. doi: 10.3402/tellusa.v50i1.14517

Therriault, J. C., Petrie, B. D., Pepin, P., Gagnon, J., Gregory, D., Helbig, J., . . Sameoto, D. (1998). Proposal for a Northwest Atlantic Zonal Monitoring Program, Canadian Technical Report of Hydrography and Ocean Sciences 194 (Tech. Rep.). Fisheries and Oceans Canada.

Thibodeau, B., de Vernal, A., \& Mucci, A. (2006). Recent eutrophication and consequent hypoxia in the bottom waters of the Lower St. Lawrence Estuary: Micropaleontological and geochemical evidence. Marine Geology, 231 (1-4), 37\{50. doi: 10.1016/j.margeo.2006.05.010

Thibodeau, B., Lehmann, M. F., Kowarzyk, J., Mucci, A., G_elinas, Y., Gilbert, D., . . Alkhatib, M. (2010). Benthic nutrient uxes along the Laurentian Channel: Impacts on the N budget of the St. Lawrence marine system. Es- tuarine, Coastal and Shelf Science, 90 (4), 195 \{205. Retrieved from http:// dx.doi.org/10.1016/j.ecss.2010.08.015 doi: 10.1016/j.ecss.2010.08.015

Thibodeau, B., Not, C., Zhu, J., Schmittner, A., Noone, D., Tabor, C., . . Liu, Z. (2018). Last century warming over the Canadian Atlantic shelves linked to weak Atlantic Meridional Overturning Circulation. Geophysical Research Let- ters, 45 (22), 12376\{12385. Retrieved from https://www.essoar.org/doi/abs/10.1002/essoar.10500026.2 doi: 10.1002/ESSOAR.10500026.2

Thornalley, D. J., Oppo, D. W., Ortega, P., Robson, J. I., Brierley, C. M., Davis, R., ... Keigwin, L. D. (2018). Anomalously weak Labrador Sea convection and Atlantic overturning during the past 150 years. Nature, 556, 227-230. doi: 10.1038/s41586-018-0007-4

Tomczak, M. (1981). A multi-parameter extension of temperature/salinity diagram techniques for the analysis of non-isopycnal mixing. Progress in Oceanography, 10, 147-171.

Tomczak, M., \& Large, D. G. (1989). Optimum Multiparameter Analysis of Mixing in the Thermocline of the Eastern Indian Ocean. Journal of Geophysical Research, 94 (C11), 1614116149. Tomczak, M., Large, D. G., \& Nancarrow, N. (1994). Identification of diapyc- nal mixing through optimum multiparameter analysis 1 . Test of feasibility and sensitivity. Journal of Geophysical Research, 99(C12), 267-274. doi: 10.1029/94jc01947

Townsend, D. W., Pettigrew, N. R., Thomas, M. A., Neary, M. G., Mcgillicuddy, D. J., \& Donnell, J. O. (2015). Water masses and nutrient fluxes to the Gulf of Maine. Journal of Marine Research, 73, 93-122. doi: $10.1038 / 141548 \mathrm{c} 0$

Townsend, D. W., Thomas, A. C., Mayer, L. M., Thomas, M. A., \& Quinlan, J. A. (2006). Oceanography of the Northwest Atlantic Shelf $(1, \mathrm{~W})$. In Robinson, a.r. and k.h. brink (eds). the sea:

This article is protected by copyright. All rights reserved. 
The global coastal ocean: Interdisciplinary regional studies and syntheses (chap. 5). Harvard University Press.

Urrego-Blanco, J., \& Sheng, J. (2012). Interannual variability of the circulation over the eastern Canadian shelf. Atmosphere - Ocean, 50(3), 277-300. doi: 10 .1080/07055900.2012.680430

Voorhis, A. D., Webb, D. C., \& Millard, R. C. (1976). Current Structure and Mixing in the Shelf/Slope Water Front South of New England. Journal of Geophysical Researches, 81 (21), 36953708. doi: 10.1029/JC081i021p03695

Wang, Z., Yashayaev, I., \& Greenan, B. (2015). Seasonality of the inshore Labrador current over the Newfoundland shelf. Continental Shelf Research, 100, 110. Retrieved from http://dx.doi.org/10.1016/j-csr.2015.03.010 doi: 10.1016/j.csr.2015.03.010

Watelet, S., Beckers, J. M., \& Barth, A. (2017). Reconstruction of the Gulf Stream from 1940 to the present and correlation with the North Atlantic Oscillation. Journal of Physical Oceanography, 47(11), 2741-2754. doi: 10.1175/JPO-D-17-0064.1

This article is protected by copyright. All rights reserved. 


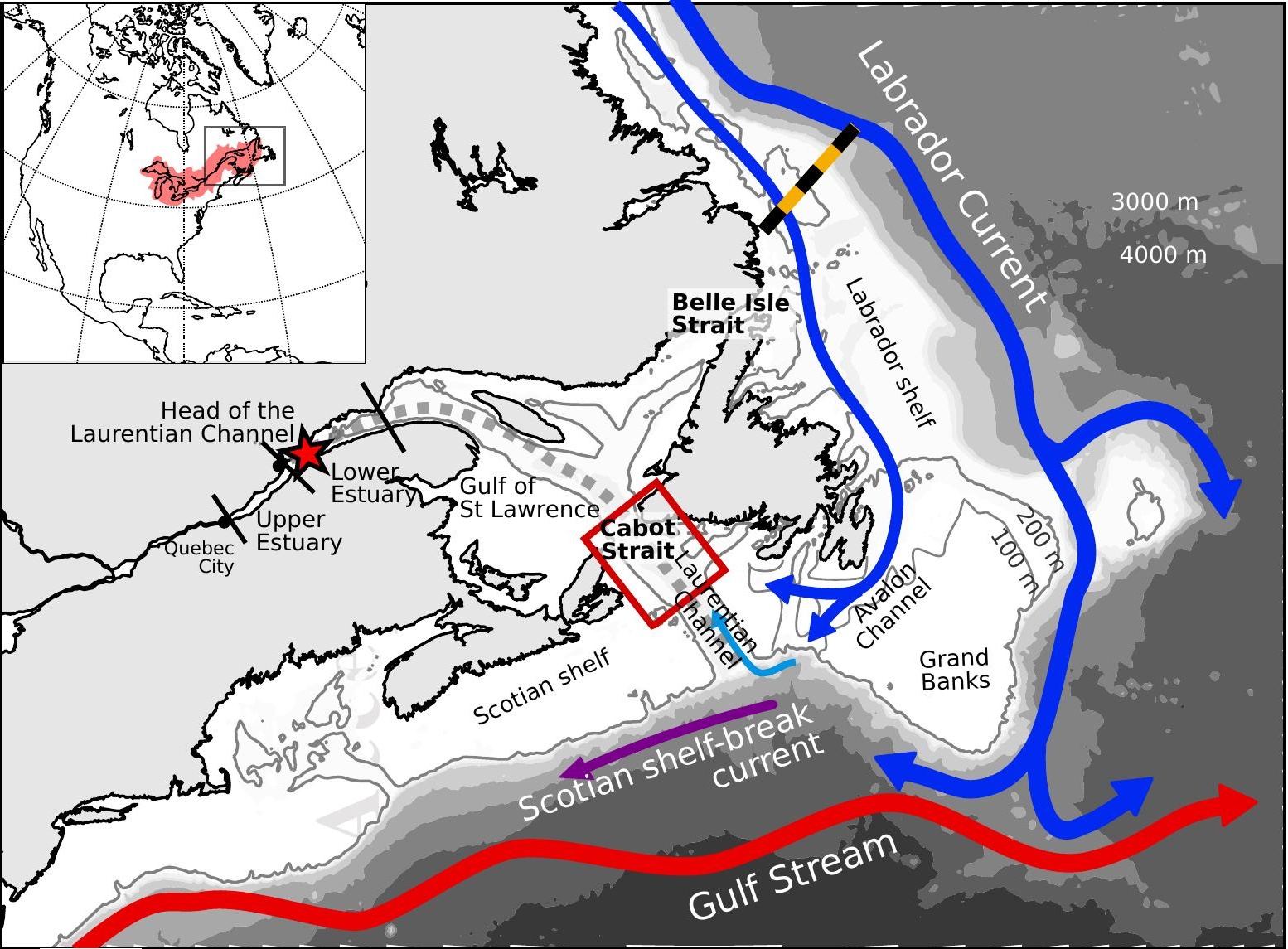



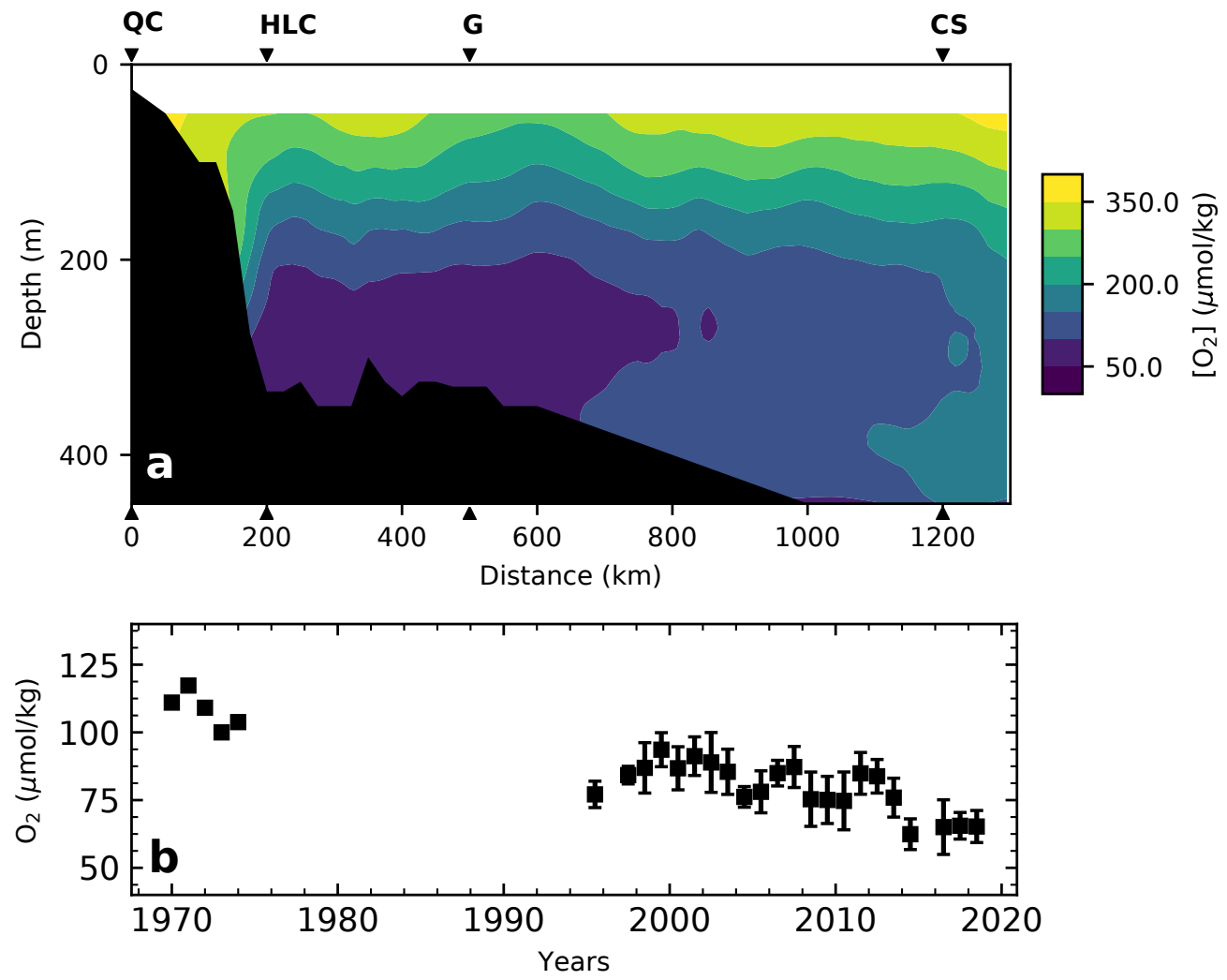


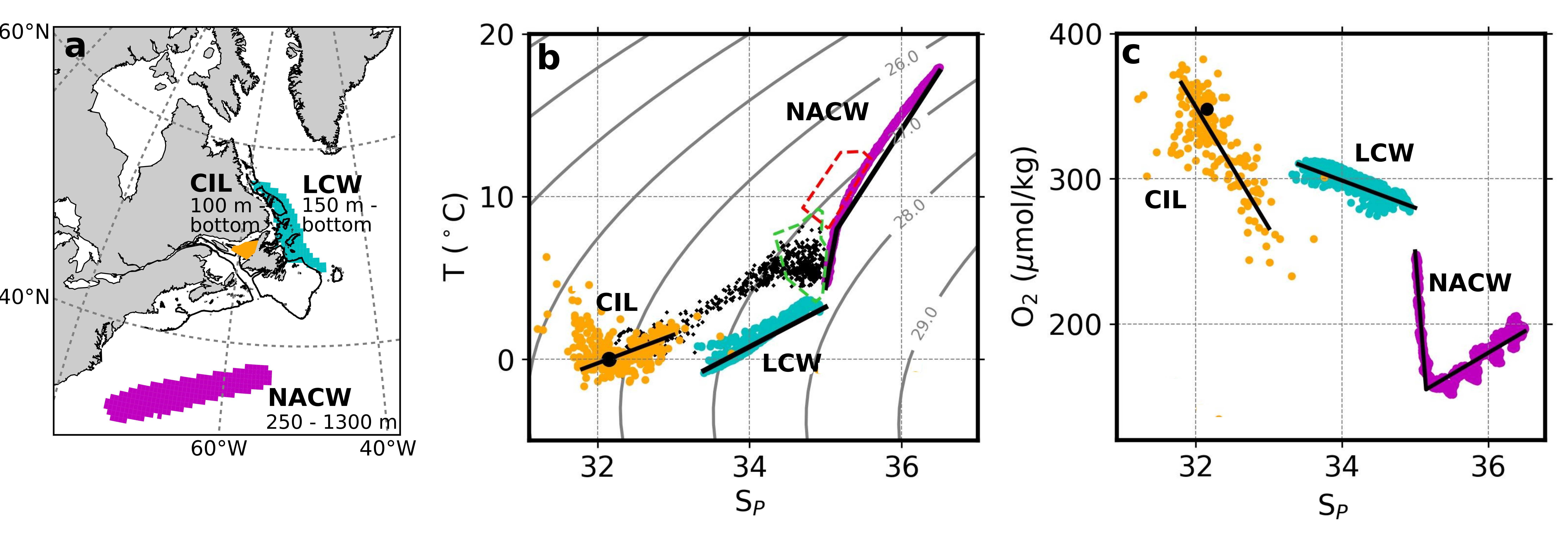




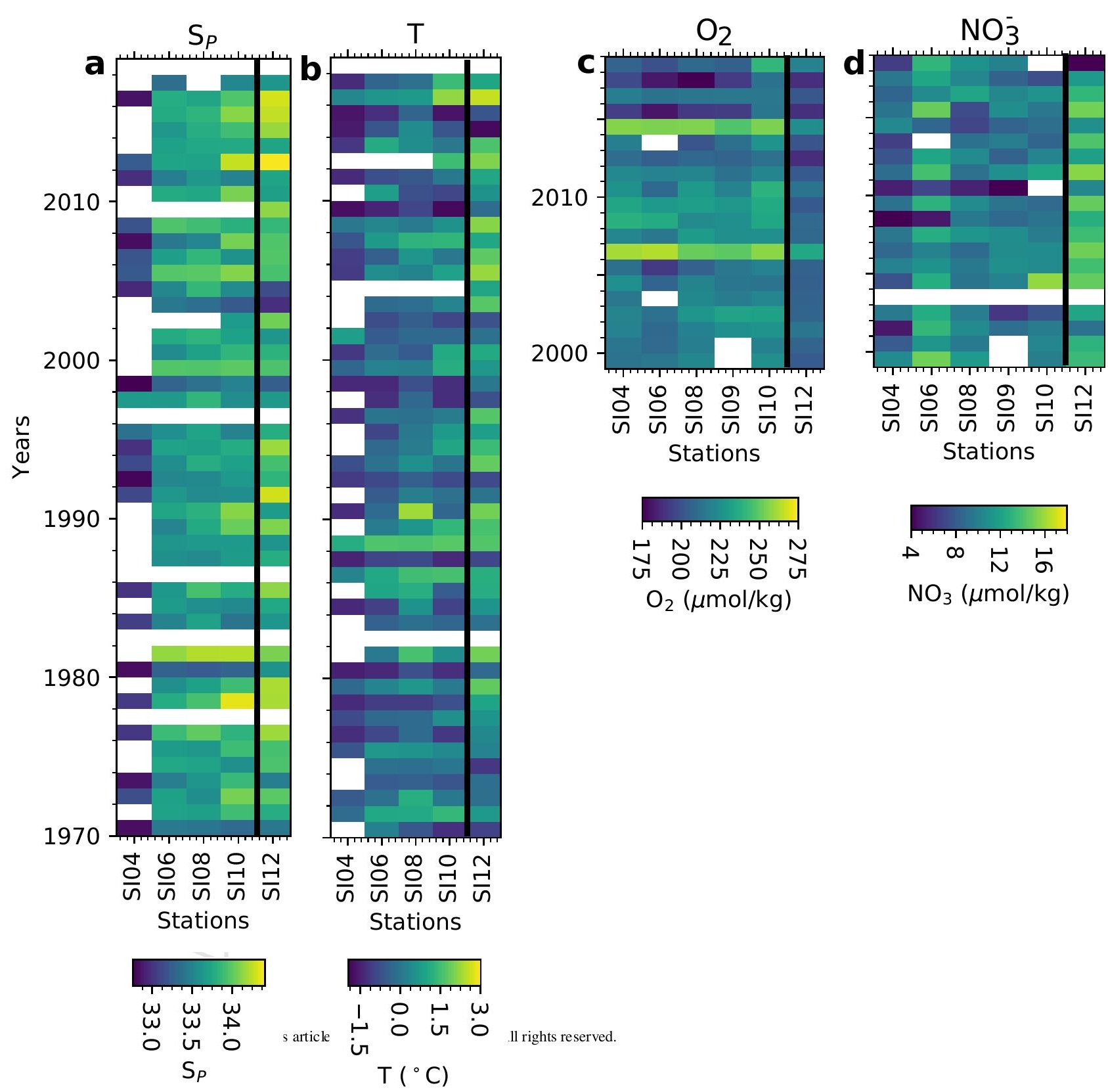



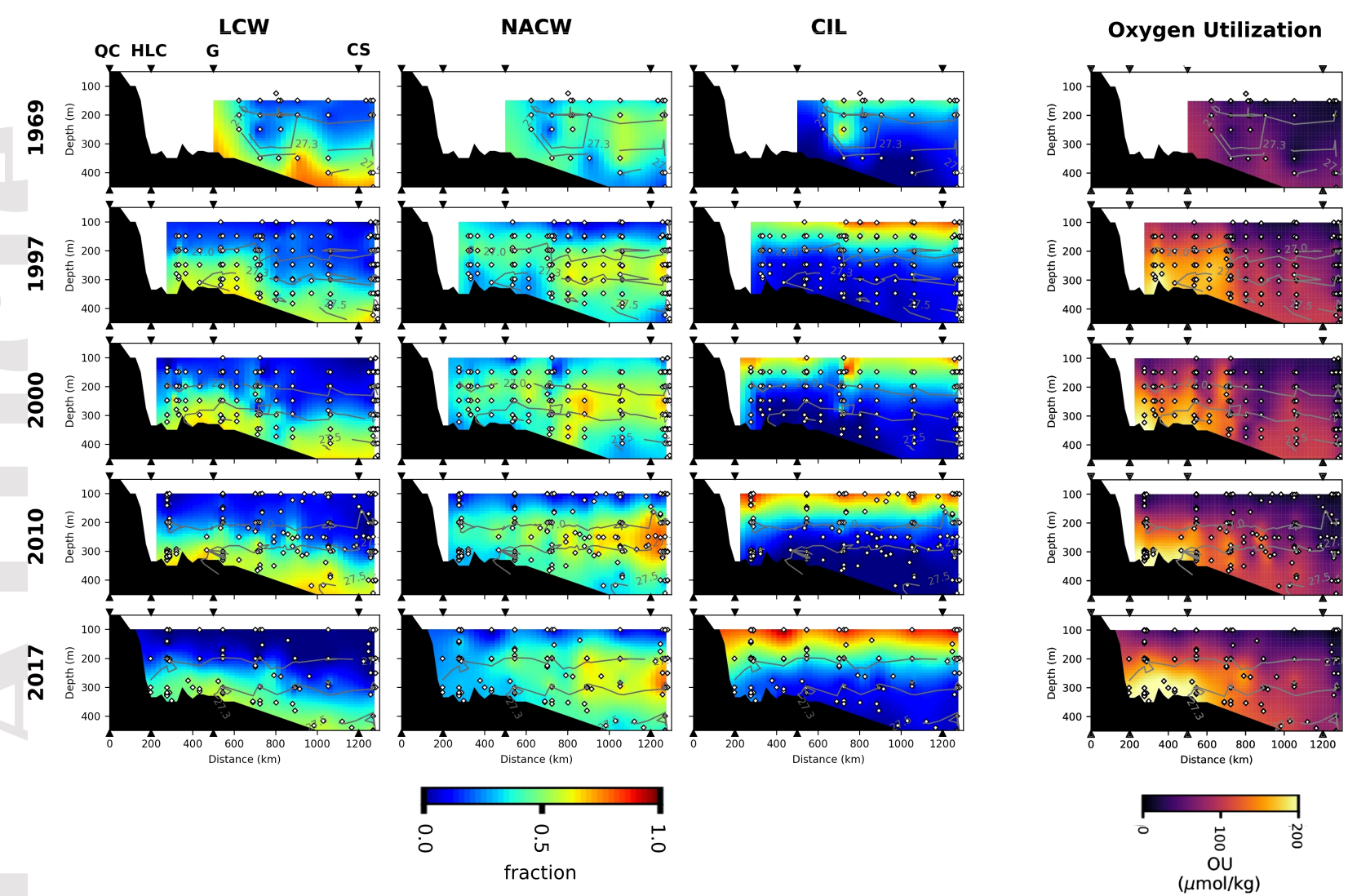

This article is protected by copyright. All rights reserved. 


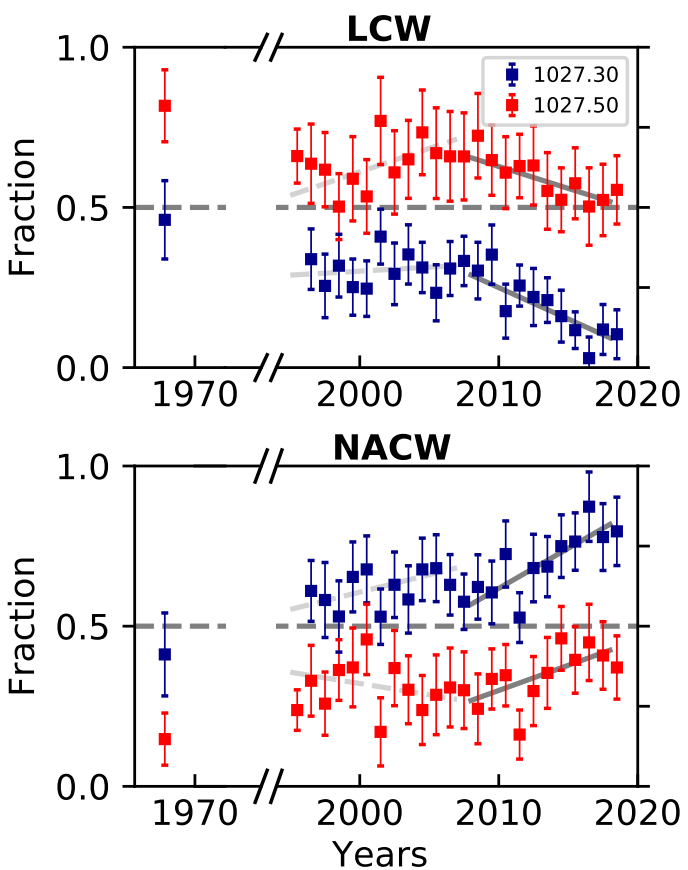




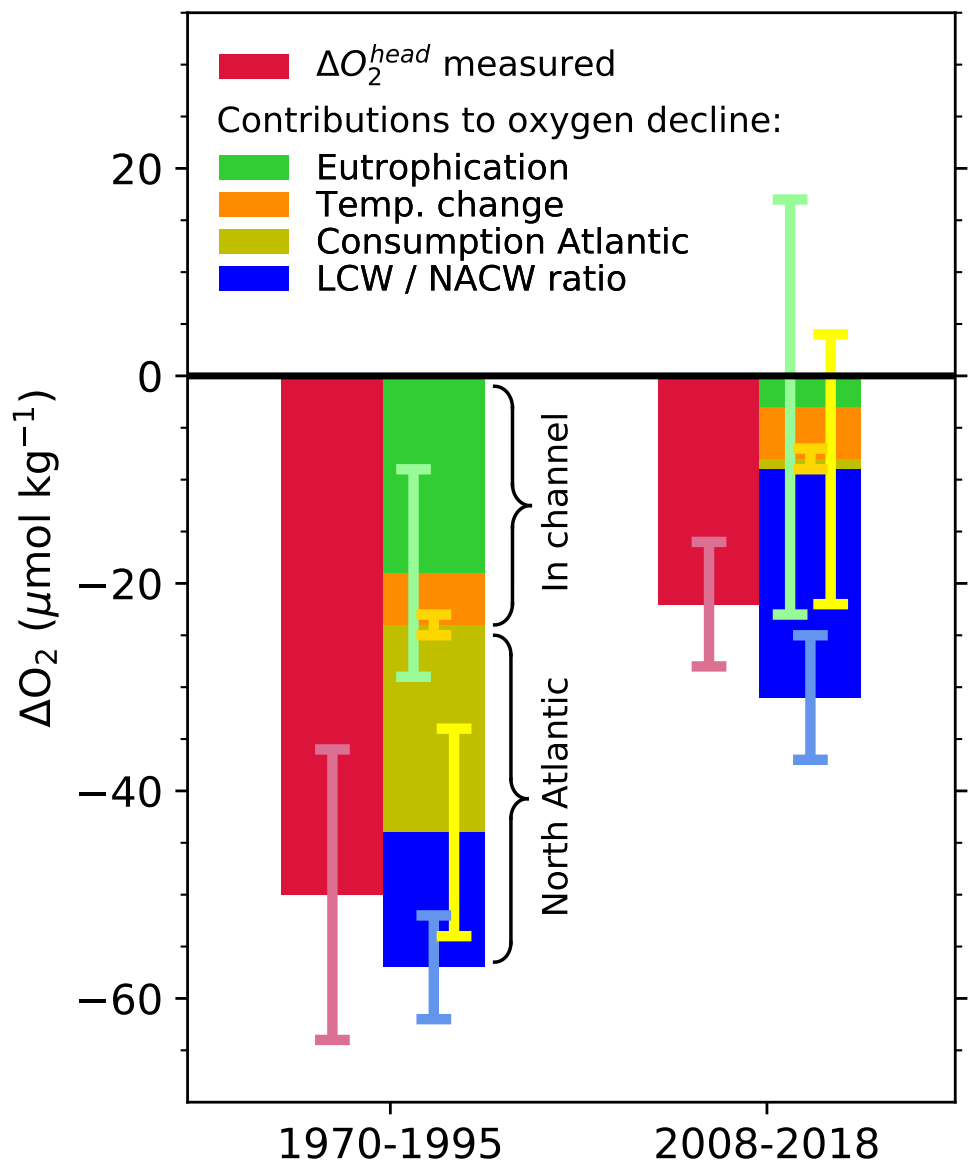




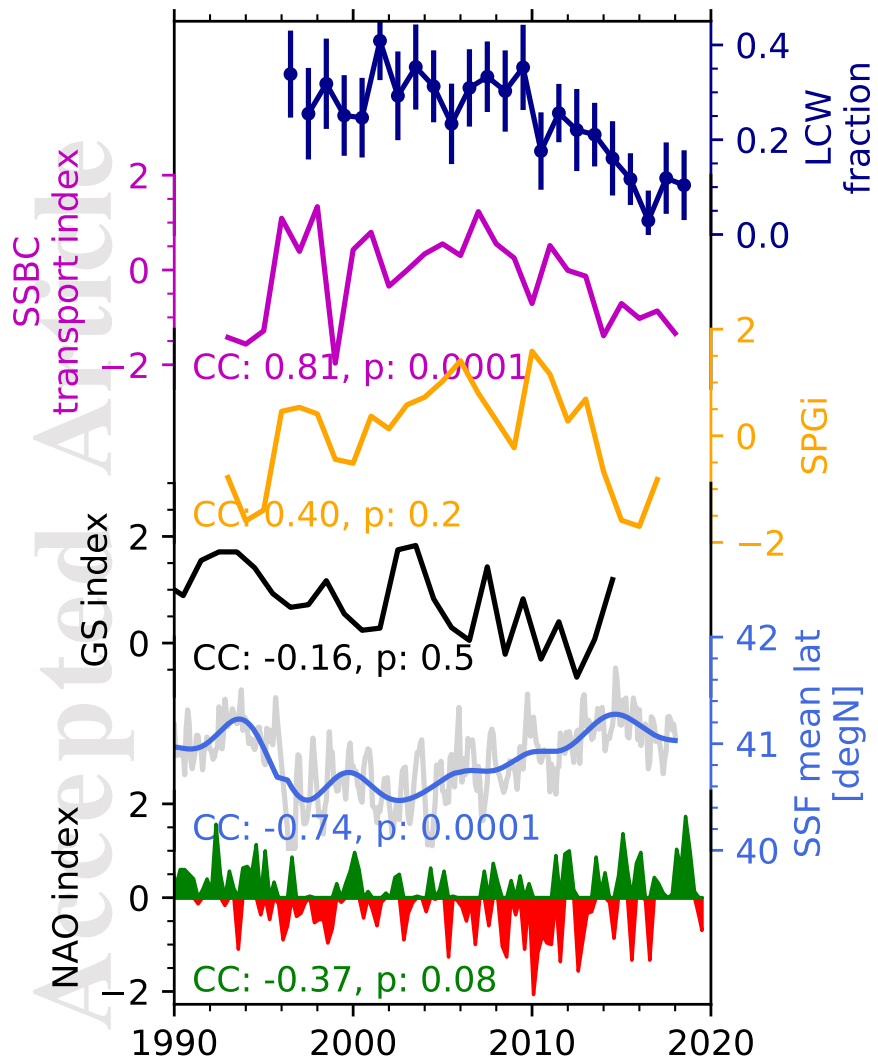

This article is protected by copyright. All imefesed. 
